Florida International University FIU Digital Commons

\title{
Identity formation and public perception in the history of American Mormonism
}

Jaquelinne M. Biver

Florida International University

DOI: $10.25148 /$ etd.FI14051161

Follow this and additional works at: https://digitalcommons.fiu.edu/etd

Part of the Religious Thought, Theology and Philosophy of Religion Commons

\section{Recommended Citation}

Biver, Jaquelinne M., "Identity formation and public perception in the history of American Mormonism" (2009). FIU Electronic Theses and Dissertations. 1704.

https://digitalcommons.fiu.edu/etd/1704 


\title{
FLORIDA INTERNATIONAL UNIVERSITY
}

Miami, Florida

IDENTITY FORMATION AND PUBLIC PERCEPTION IN THE HISTORY OF AMERICAN MORMONISM

\author{
A thesis submitted in partial fulfillment of the \\ requirements for the degree of \\ MASTER OF ARTS \\ in
}

RELIGIOUS STUDIES

by

Jaquelinne M. Biver 
To: Dean Kenneth Furton

College of Arts and Sciences

This thesis, written by Jaquelinne M. Biver, and entitled Identity Formation and Public Perception in the History of American Mormonism, having been approved in respect to style and intellectual content, is referred to you for judgment.

We have read this thesis and recommend that it be approved.

Albert Wuaku

Oren Stier

Lesley Northup, Major Professor

Date of Defense: March 23, 2009

The thesis of Jaquelinne M. Biver is approved.

Dean Kenneth Furton

College of Arts and Sciences

Dean George Walker

University Graduate School

Florida International University, 2009 


\section{ACKNOWLEDGMENTS}

I offer sincere thanks to the members of my thesis committee and to the faculty and staff of the Religious Studies Department for their encouragement, support, and guidance. Dr. Nathan Katz' models of acculturation sparked my interest in the communal identities of religious movements. Dr. Albert Wuaku has provided insight into models of outsider groups and a social and cultural perspective. Dr. Oren Stier guided me in the study of communal memory, identity, and boundary maintenance. Dr. Gudorf has provided a role model of academic excellence and compassion, juggling roles and supporting the entire department. Dr. Lesley Northup has provided continued support and guidance, aiding me in my understanding of new religious movements and the state of myth in America. I am grateful to the students, faculty, and staff of the Religious Studies Department for their camaraderie, insight, and encouragement of excellence. 


\section{ABSTRACT OF THE THESIS \\ IDENTITY FORMATION AND PUBLIC PERCEPTION IN THE HISTORY OF AMERICAN MORMONISM}

by

Jaquelinne M. Biver

Florida International University, 2009

Miami, Florida

Professor Lesley Northup, Major Professor

This study inquires into the institutional identity of the Church of Jesus Christ of Latter-day Saints since its founding in 1830 . The study takes a historical stance in discussing the relationship between American public perceptions and the Church's developing internal identity, tracing these changes through three distinct historical stages. Building on the works of historians and sociologists such as Jan Shipps, Armand Mauss, and Terryl Givens, this study hopes to contribute to the understanding of new religious movements and the progression from sect to church.

The study finds that Mormon identity and American perceptions of Mormons have had an inter-influential relationship, each responding and re-forming in turn. The LDS Church has progressed from sect to church as tensions with the host society have lessened. Currently, the Church is at an optimum level of tension with the host society, maintaining a distinct identity while enjoying conventional acceptance. 


\section{TABLE OF CONTENTS}

CHAPTER

PAGE

I. Introduction: Mormon Identity and Public Perceptions, Theory and Method 1 Theoretical framework 5

Methodology

Key Themes

II. Mormon Identity and Public Perception during the Foundational Period, 14 $1830-1890$

III. Toward Assimilation and Modernization, 1900-1960s 31

IV. Reclamation of Distinctiveness, 1960s-2000 39

V. 2000 and beyond, Mormonism in the Twenty-first Century: an American Church 47

VI. Conclusion and implications for future research $\quad 54$

$\begin{array}{lr}\text { WORKS CITED } & 59\end{array}$ 


\section{Introduction: Mormon Identity and Public Perceptions, Theory and Method}

The story of the Church of Jesus Christ of Latter-day Saints ${ }^{1}$ is a model case study in the successful acculturation of a new religious movement ${ }^{2}$ within the pluralistic framework of American culture and society. At the outset of the twenty-first century, the Church holds a special place in American history and society, balanced carefully between assimilation and distinctiveness, inclusion and tension. This balance has been achieved over the course of a "natural history" divided into broad, often overlapping, stages. The schema of historical stages presented herein are demarcated for convenience' sake; for the purposes of furthering the discussion, they are an imposed structure on truly "natural" history, a framework by which to map the process of Mormon identity in light of public reaction.

The first stage began in 1830 and lasted through about 1890 . This first stage was characterized by foundational activities in New York, Ohio, Missouri, and Illinois, and finally, settlement and the process of institutionalization in Utah. Early Mormon communities were often ridiculed in the local presses of the towns where they settled; their novel religious beliefs, dependence on extra-canonical sacred texts such as the Book

\footnotetext{
'The Church of Jesus Christ of Latter-day Saints, hereafter interchangeably referred to as the Church, Mormonism, or in shortened form LDS. Adherents are commonly referred to as Mormons or Latter-day Saints.

${ }^{2}$ The Church can be classified as a new religious movement, founded in America by a charismatic leader in opposition to society. Similarly, the Church fits the profile of a sect, a breakaway of the predominant regional Protestantism. As such, the Church's history can be viewed in light of its evolution from sect to Church, bearing in mind the process of acculturation for a new religious movement.

3 Armand L. Mauss, "Identity and Boundary Maintenance: International Prospects for Mormonism at the Dawn of the Twenty-first Century," in Mormon Identities in Transition, ed. Douglas Davies (New York: Cassell, 1996), 10.
} 
of Mormon, communitarian ideals, and millenarian tendencies repeatedly caused conflict with neighboring communities. ${ }^{4}$ This conflict and persecution played an important role in early Mormon identity formation, adding strength to the growing self-identification of a persecuted and elect people appointed by God to restore the one true church. Beliefs surrounding the elect status of Mormons only further fueled the conflicts between Mormons and others and within the Mormon camp. Historian Kathleen Flake notes that "Mormonism's history of persecution is part of their understanding of who they are... persecution became a measure of their righteousness, as religious [people] are wont to do. ${ }^{\circ 5}$

Mormon identity during this first stage can be characterized as an identity "forged in the fire of... persecutions ${ }^{\prime 6}$ and in the spirit of distinctiveness, especially against other religious denominations. Americans perceived Mormons as peculiar, threatening, and even comical during the foundational period, as evidenced by commentary in the local presses of the time, in addition to literature, pamphlets, and journals. ${ }^{7}$ Mormons rejected being identified with evangelical Christians, using the press to publish "a voluminous outpouring of diaries, journals, and letters asserting the group's distinctive identity."8 The

\footnotetext{
${ }^{4}$ As noted by Underwood, "During much of the first sixteen years of Mormon history, the Saints experienced severe persecution and crisis conditions." Grant Underwood, The Millenarian World of Early Mormonism (Urbana: University of Illinois Press), 1993.

${ }^{5}$ Public Broadcasting Station, "The Mormons: Interviews: Kathleen Flake," WGBH Educational Foundation, http://www.pbs.org/mormons/interviews/flake.html.

${ }^{6}$ Leonard J. Arrington, and Davis Bitton, The Mormon Experience: A History of the Latter-day Saints (Urbana: University of Illinois Press, 1992), 2.

${ }^{7}$ M. Hamlin Cannon, "Contemporary Views of Mormon Origins," The Mississippi Valley Historical Review 31 (1944).
} 
printing press, which allowed the publication and dissemination of the Book of Mormon and gave voice to Mormons and evangelicals, also gave voice to dissenters; the publication of these materials allows these voices to be heard, interpreted, and put into context over a century later. However, as identified by scholars of Mormon history, antiMormon rhetoric and suspicion does not fully account for the incidences of conflict and violence; some of the tension was undoubtedly contributed by the Mormons themselves:

Divisions within the LDS community paved the way for disaster in both Kirtland and Nauvoo. In Missouri, the Saints were so certain that divine mandate had made this land their inheritance that they uttered words and took actions that undoubtedly added to the old Missouri settlers' grievances against the Saints.

After the conflict of the first half of the foundational period, coming to a head with the murder of Joseph Smith in Nauvoo, Illinois, the Church's second leader, Brigham Young, led Mormon settlers from Nauvoo to the Salt Lake Valley, where the Mormon world headquarters has thrived to the present day. The trek, or exodus, to Utah marks the beginning of the end of the first stage. The second half of the first stage, still a foundational period, is characterized by settlement, along with community, ecclesiastical, and authoritative organization in Utah. The first stage can be said to have phased out around the end of the nineteenth century, with an important bridge between the first and second stages being the public denunciation of polygamy by Church President Wilford Woodruff in 1890.

Generally, the second stage can be said to begin around 1900, lasting roughly to the 1960s. It was characterized by a high degree of assimilation into the dominant culture,

\footnotetext{
${ }^{8}$ Candy Gunther Brown, The Word in the World: Evangelical Writing, Publishing, and Reading in America, 1789-1880 (Chapel Hill: The University of North Carolina Press, 2004), 43.

${ }^{9}$ Jan Shipps, Sojourner in the Promised Land: Forty Years Among the Mormons (Chicago: University of Illinois Press, 2000), 51-2.
} 
modernization, reconstruction, and community building. During this second stage, the Church was transformed into an American institution as greater emphasis was placed on Christian and American qualities, such as the centrality of Jesus Christ and his appearance in the country, as claimed in the Mormon faith.

The third stage, beginning with the 1960s and lasting throughout the remainder of twentieth century, saw the Church once again emphasizing its own unique identity during a period of retrenchment, a scaling back of assimilation and the reclamation of distinctiveness. Although the Church continued its highly organized public-image campaign and continued to emphasize its Christian and American attributes, there occurred simultaneously reclamation of Mormon history, heritage, and identity as a restored Church with its own distinctive theology. In this stage the Church reached an apex of belonging while simultaneously maintaining its distinctiveness as a people, a Church, and a history. The retrenchment of the twentieth century can be described as a gradual scaling back of the emphasis on Americanization, Christianization, and assimilation, replaced by a stronger emphasis on the uniqueness of Mormonism, its doctrines, values, and people. In the early years of the twenty-first century, we are witness to a culmination of these stages, when Mormons have reached a level of "optimum tension" with the greater society. A level of "optimum tension" with the host society has been recognized by sociologists as a significant determinant of "the survival and growth of any religion." 10

\footnotetext{
${ }^{10}$ Armand L. Mauss, The Angel and the Beehive: the Mormon Struggle with Assimilation (Urbana: University of Illinois Press, 1994), 9.
} 


\section{Theoretical Framework}

The historical stages outlined above provide a framework with which to explore the relationship between Mormon identity and American perceptions of Mormons and Mormonism ${ }^{11}$ since 1830 . The relationship between the internal collective identity of a group and the larger society's perceptions of that group is essentially between the formation of a people with a distinct, collective identity and the history of American ideas and attitudes about outsiders. Mormon collective identity has undergone major shifts since its founding. Mauss calls these shifts a "process of alternating periods of assimilation and retrenchment" that make up a "natural history" that can be applied to successful new religious movements-that is, those that are integrated into society while retaining a truly distinctive collective, or denominational, identity. ${ }^{12}$ Modern American social-scientists H. Richard Niebuhr and Benton Johnson interpret "the Weber-Troeltsch historical model," or church-sect typology, as supporting the theory of a:

natural (and seemingly inevitable) evolutionary process by which new religions begin as 'sects' or schisms of older ones that have lost their sectarian zeal and grown too comfortable with the surrounding culture; that is, they have become 'churches'. ${ }^{13}$

This view of "natural history" sees a movement progress from "sect" to "Church," to full-fledged organizational institution entrenched in the dominant society. ${ }^{14}$ Mauss

\footnotetext{
${ }^{11}$ The Church of Jesus Christ of Latter-day Saints.

${ }^{12}$ Armand L. Mauss, "Identity and Boundary Maintenance: International Prospects for Mormonism at the Dawn of the Twenty-first Century," in Mormon Identities in Transition, ed. Douglas Davies (New York: Cassell, 1996), 10.

${ }^{13}$ Armand L. Mauss, and Philip Barlow, "Church, Sect, and Scripture: The Protestant Bible and Mormon Sectarian Retrenchment," Sociological Analysis 52 (1991): 398.
} 
develops the idea of "optimum tension" within the framework of the sect-church model for new religious movements. His theoretical work, along with the works of others, helps to shape the scope of this work.

\begin{abstract}
A key element implicit in...classical 'sect-church' scheme, made explicit in the more recent work of Stark and Bainbridge (1985), is the degree of tension existing between a religious movement and its surrounding culture. New sects and cults typical begin in a state of high tension with their host societies and cultures; that is, they promote ideologies, requirements, and lifestyles among their members that are noticeably deviant from those of the surrounding normative environments. From this point of view, one way of understanding the evolution from sect (or cult) to church is to describe it as a transition from high tension to low tension with the host society. ${ }^{15}$
\end{abstract}

Mormonism has survived and thrived in America and more recently, globally, as a result of the optimum level of tension between Mormons and America, achieved through a history of assimilation and retrenchment.

A process of routinization or a sort of disenchantment often takes place after the fall of a charismatic leader such as Joseph Smith. A charismatic leader, according to Max Weber and others, is one who claims authority based on extraordinary, even otherworldly, gifts, and whose authority is acknowledged by a community. Charismatic leaders frequently possess a fiery, contagious, often revolutionary zeal, transmitted to the entire community. However the initial state of fervor state cannot be maintained indefinitely and eventually if a sect is to survive and thrive, a process of routinization must take place. Christianity is an obvious example of this routinization process. Throughout the centuries, the church lost its early fervor and was reconstructed into a largely bureaucratic affair. This was a process of necessity occurring at a subconscious, organizational level. Here charisma moves from a psychological condition affecting a

\footnotetext{
${ }^{14}$ See William W. Mayrl, "Marx' Theory of Social Movements and the Church-Sect Typology," Sociological Analysis 37 (1976).

${ }^{15}$ Armand L. Mauss and Philip Barlow, "Church, Sect, and Scripture: The Protestant Bible and Mormon Sectarian Retrenchment," Sociological Analysis 52 (1991): 398.
} 
leader and a population devoted to that leader, to a social, organizational process whereby authority is in the hands of clergy and trained professionals. These professionals may or may not have charismatic personalities, but their authority comes from the office they hold, not from any personal or divine attributes or gifts. The Church of Jesus Christ of Latter-day Saints presents an interesting model for this process. Throughout the Church's history, prophetic authority has continued to be central to the Church; indeed it is fundamental to Mormon theology. The continued presence of prophetic, leadership did not seem to have an effect on the routinization process, however, and the American LDS Church remains an excellent case study of church-sect and charismatic authority typologies.

A corresponding theoretical framework is that of the Vitality Curve of religious institutions. ${ }^{16}$ According to the Vitality Curve, a religious institution is founded in myth, ritual, and symbol. If these elements successfully engage followers, periods of expansion and stabilization follow. A breakdown period inevitably occurs following stabilization, during which doubt sets in-members begin to experience doubt in the original myths and symbols of the institution, followed by ideological doubt, ethical doubt, and finally, absolute doubt. At this extreme end of the curve, the institution is in distress. In order to survive it must return to its foundations and renew its mythic system along with its rituals and symbols. The Vitality Curve model occurs at both the institutional and the individual level. Joseph Smith steeped Mormonism in a rich mythic, symbolic, and ritualistic system that has been continually renewed by subsequent dynamic leadership. Smith combined religious and national myths and rituals in powerful ways, sacralizing Mormon

\footnotetext{
${ }^{16}$ As discussed by Bernard Hostie, S.J., in unpublished lecture notes.
} 
communities and the American continent. Dividing the stages of American LDS history as outlined in this paper are periods of transition in which the Church has revived its myths, rituals, and symbols to remain vibrant.

\section{Methodology}

In order to conceptualize the "natural history" of Mormon identity as outlined by Mauss and others and place it in context, I will investigate the relationship between public perceptions of Mormons in America and the developing sense of identity within the Church. My paper is an historical analysis of Mormonism with a focus on the formation of an institutional identity. The goal is a general understanding of the ways in which internal identity and publically imposed identities interact on a grand scale to refine a collective sense of identity. Within these sources lie a wealth of historical and theoretical information and connections to primary source material. The current study relies on primary sources where available and appropriate, in conjunction with academic secondary sources. ${ }^{17}$ With the aid of these sources, the study draws on, synthesizes, and attempts to build upon the work of lifelong scholars of Mormon history such as Jan Shipps, Mauss, Terryl Givens, and Leonard Arrington, to name a few, to gain a greater understanding of how Mormon identity has developed in relation to the way Americans have studied and thought about Mormons.

A general picture of American perceptions of Mormons can be traced through the historical periods as outlined above. Historians, sociologists, and scholars from various fields have attended to the Mormon problem. In addition, the current work contributes to

\footnotetext{
${ }^{17}$ Primarily scholarly historical and sociological studies about Mormonism.
} 
ongoing inquiry into Mormon identity by exploring the dimension of public perception in America and its inter-influential relationship with Mormon identity formation. Jan Shipps has noted the difficulty in ascertaining a clear understanding of public perception in any given time period; her meticulous study of available sources for piecing together public perceptions of Mormons is a contribution to the field that I will make use of in the current study.

Key Themes

\section{Identity and Community}

The connection between Mormon identity and its history, or mythic narrative, is clear to the lay observer and has been extensively noted in the literature. In an observable and very real way, Mormon history is Mormon identity. One can envision "a people" as a community. I will define a community as a "people" with a distinct identity living amongst other peoples, or communities, with their own distinct identities in turn. A community shares a common culture; the common culture may be based on shared history, mythic narratives, rituals, norms, and value systems. Emile Durkheim equates a church with a moral community, whose practices he identifies with "the sacred." 18 In distinguishing between "religion" and "magic," Durkheim points out that "a church is not simply a priestly brotherhood; it is the moral community formed by all believers in the same faith, worshippers as well as priests." 19

\footnotetext{
${ }^{18}$ Emile Durkheim, The Elementary Forms of Religious Life (New York: Oxford University Press, 2001): xxii.

${ }^{19}$ Emile Durkheim, The Elementary Forms of Religious Life (New York: Oxford University Press, 2001): 44.
} 
Communities are marked by deep, intimate and co-operative ties between members. In this sense, 'community' is close to Durkheim's idea of social solidarity, which emerges from commitment to a shared set of values... 'the collective conscience. ${ }^{20}$

In the case of American Mormonism, the strong sense of community, belonging, and shared values is well documented in scholarship and can be witnessed upon a visit to Salt Lake City, Utah. James T. Duke found that "LDS people" are "more likely to believe" themselves "to be a strong member of [their] church... and to make greater financial contributions to the church" than the average U.S. churchgoer. ${ }^{21}$ The sense of collective identity permeates individual identity and encourages incorporation of the community identity into the self and family. The individual, family, and community are held together by their common culture, their common story, and a highly organized central authority that keeps careful records of Church members. Contributing to this high level of social cohesion is the doctrine of celestial marriage. According to Mormon theology, "the family is ordained of God." 22 For members in good standing, ${ }^{23}$ matrimony involves an eternal "sealing" of oneself to one's partner, both physically and spirituality. In this process, the everlasting souls of husband and wife, and all future offspring, are sealed together for eternity.

The cultural identity of a community and the inherent conflict in identity formation are both themes worthy of exploration. The cultural identity of a community is

${ }^{20}$ R. Cohen and Kennedy, P. 2000, Global Sociology, MacMillan, London, p. 375

${ }^{21}$ James T. Duke, "Latter-day Saint exceptionalism and membership growth," in Mormon Identities in Transition, ed. Douglas Davies (New York: Cassell, 1996), 49.

${ }^{22}$ Read by President Gordon B. Hinkley at the General Relief Society Meeting on September 23, 1995, in Salt Lake City, Utah, "The Family: A Proclamation to the World," The Church of Jesus Christ of Latterday Saints, http:/www.Ids.org/library/display/0,4945,161-1-11-1,00.html.

${ }^{23}$ Those holding a "Temple Recommend" from the Church, this certifies that the parishioner is worthy of witnessing and partaking in Temple Rites such as Celestial Marriage. 
that of a people defined internally by history, myth, and shared meanings, and perceived externally by non-members. Clifford Geertz defines culture as mutually understood "webs of significance" ${ }^{24}$ spun by humankind; suspended in these webs, In order for a community to maintain a distinct identity in a pluralistic society, it must avoid absorption into neighboring communities and loss of distinctiveness. Identity is created by distinguishing self from other, in the cases of either communities or individuals. Regina Schwartz contends that the process of maintaining a distinct identity as a people is essentially "an act of distinguishing and separating from others, of boundary making and line drawing. ${ }^{, 25}$ In distinguishing between insiders and outsiders, conflict, and therefore, hostility, is created. Conflict is contained by careful maintenance of those boundaries.

\section{Conflict}

Conflict was an essential component of Joseph Smith's own identity, whose stories of early persecutions are now canonized in sacred Church history. Incidences of conflict and persecution in New York, Ohio, Missouri, and Illinois contributed to a growing Mormon religious and communal self-identification of distinctiveness, chosenness, and righteousness. Early Mormons shared a sense of collective identity in relation to the established culture built on "sharp boundaries between themselves and surrounding 'gentile' settlements. ${ }^{, 26}$ One distinctive aspect of this identity of self against

\footnotetext{
${ }^{24}$ Clifford Geertz, The Interpretation of Cultures (New York: HarperCollins Publishers, 1973), 5.

${ }^{25}$ Regina M. Schwartz, The Curse of Cain: The Violent Legacy of Monotheism (Chicago: University Of Chicago Press, 1997), 5.

${ }^{26}$ Laurence R. Moore, "Insiders and Outsiders in American Historical Narrative and American History," The American Historical Review 87 (1982): 400.
} 
other is a historical narrative of persecution. By the time Mormons had been driven from Missouri, Ohio, and Illinois, "their unity and sense of uniqueness" had been "forged in the fire of these persecutions. ${ }^{, 27}$ Historian Kathleen Flake notes that:

Mormonism's history of persecution is part of understanding who they are and who they were... how they present themselves in the world... historically. Persecution became a measure of their righteousness, as religious [people] are wont to do... it also shored up their external boundaries against Protestant America. ${ }^{28}$

Scholarship of the past few decades is generally in agreement that "the Mormons did suffer from persecution, that they brought at least some of it on themselves, [and] that the anti-Mormons overreacted and resorted to a violence that deserved condemnation"29. Arrington points out that the Mormon experience of "religion" encompassed far more than merely those elements typically considered religious; cultural, civic, and economic norms and ideals are included in the Mormon experience of religion. The Mormon "goal of community building... inevitably meant political and economic tension with their neighbors." 30

Tension between the Mormons and their contemporaries resulted from several factors, including (1) their salvation rhetoric-i.e., "their insistence that only they possessed the 'correct' way to salvation"; (2) the Mormon organizational propensity towards community and self-sufficiency ${ }^{31}$-i.e., the "tendency to establish political and

${ }^{27}$ Leonard J. Arrington and Davis Bitton, The Mormon Experience: A History of the Latter-Day Saints, (Urbana: University of Illinois Press, 1992), 2.

28 "The Mormons . Interviews . Kathleen Flake | PBS," PBS, http://www.pbs.org/mormons/interviews/flake.html.

${ }^{29}$ Arrington, et al. 62

${ }^{30}$ Arrington, et al. 62

${ }^{31}$ Joseph Smith longed for a "utopian society separate from the rest of the world" (Park 238), an urge that informed city and community planning, and added to the Mormon threat in the eyes of contemporaries. 
economic control in areas where they settled"" (3) their "attempts to establish a theocratic state;" (4) and later, their practice of polygamy. American treatment of outsiders, particularly outsiders with such deep ideological, communal, and economic peculiarities, contributed to anti-Mormon rhetoric and persecution such as tar and feathering, attacks on Mormon settlers in Ohio, Missouri, and Illinois, and the mob execution of Joseph Smith in 1844.

Identity, community, and conflict are recurring themes in the history of American Mormonism. The theme of conflict plays a larger role in the early years of the Church, contributing to the identity of an elect, persecuted people. Later in Mormon history, conflict with society is lessened as the processes of acculturation take place. This lessening of conflict is inherent in the theoretical evolution from sect to Church. Mormonism displays both the characteristics of a new religious movement-founded in opposition to the prevailing culture by a charismatic leader in recent history-and of a breakaway sect from the popular Protestantism. Accordingly, the development of the Church as an institution and as a people offers a case study in the growth of a new religious movement in America, and in the evolution from sect to Church. 


\section{Mormon Identity and Public Perception during the Foundational Period, 1830- 1890}

In the spring of 1820 , Joseph Smith Jr. retired to the woods near his home in Palmyra, New York, and offered a simple prayer to our Father in Heaven. This humble prayer set into motion a series of events that brought forth The Church of Jesus Christ of Latter-day Saints from its obscure beginnings in upstate New York to a worldwide church. ${ }^{32}$

The answer to Smith's prayers came in a series of revelations that led to his writing/translation of the Book of Mormon, "a record of God's dealings with the ancient inhabitants of the Americas [that] contains, as does the Bible, the fulness of the everlasting gospel. ${ }^{933}$ According to official Church History, Smith continued to receive revelations for the remainder of his life, passing the mantle of prophetic and revelatory authority onto the subsequent leadership of the Church. Throughout the foundational period of the Church, roughly from 1830 through 1890 , the Church was defined by leadership, ongoing prophecy, and conflict. In turn, Americans viewed Mormons during this time in terms of those same three concepts-its hierarchical and Church-driven leadership, the heretical (to Christianity) doctrine of ongoing prophecy, and the religious, political, and economic threat posed by thriving new religious communities.

The Church of Christ, later officially named the Church of Jesus Christ of Latterday Saints, was instituted in 1830 in Palmyra, New York, by Joseph Smith and five others. Smith's company that day consisted of his brothers, Hyrum and Samuel, along with Oliver Cowdery and brothers Peter and David Whitmer. ${ }^{34}$ The conflict and scrutiny

\footnotetext{
32 "Approaching Mormon History - LDS Newsroom," Newsroom: The Church of Jesus Christ of Latter-day Saints, http://newsroom.Ids.org/ldsnewsroom/eng/commentary/approaching-mormon-history.

${ }^{33}$ From the Introduction to The Book of Mormon, ed. Joseph Smith, Jr. The Church of Jesus Christ of Latter-day Saints.

${ }^{34}$ See Rodney Stark and Reid L. Neilson, The Rise of Mormonism (Columbia: Columbia University Press, 2005).
} 
surrounding the formation of the church and the publication of its sacred scripture, the Book of Mormon, foreshadowed the years of conflict ahead. In January of 1830, roughly three months before the official establishment of the church, a local progressive newspaper, The Reflector, secured and published some portions of the yet to be published Book of Mormon. Obediah Dogberry, editor of the Reflector, published subsequent satirical and critical pieces about the newly formed local religion, mockingly calling the Book of Mormon a "Gold Bible." 35 In April, the Reflector published an anonymous letter complaining of Hyrum Smith's disrespectful nature towards those who would "denounce the imposition of the 'Gold Bible." 36 Dogberry continued to publish scornful pieces about the origins of the Church, publishing a satirical account "in pseudo-Biblical language" of the origins of the Book of Mormon in June of that same year. ${ }^{37}$

One year later, in 1831, Smith and his followers migrated from Palmyra to establish headquarters in Kirtland, Ohio. In Kirtland, Smith was able to gather his followers to him and form the first major Mormon community. Between the years of 1832 to 1836 , the first Mormon temple was constructed in Kirtland. The Community of

\footnotetext{
${ }^{35}$ Cannon 1944, 262; This was in reference to Smith's claim that the Book of Mormon was translated from Golden Plates buried in the hills of Palmyra. Smith was shown the location of these stones and given mystical means of interpreting them by angelic visitations.

${ }^{36}$ As published in The Reflector, April 19, 1830. M. Hamlin Cannon, "Contemporary Views of Mormon Origins," The Mississippi Valley Historical Review 31 (1944): 263.

${ }^{37}$ As published in The Reflector, April 19, 1830. M. Hamlin Cannon, "Contemporary Views of Mormon Origins," The Mississippi Valley Historical Review 31 (1944): 264.
} 
Christ $^{38}$ now maintains the historic site at Kirtland, preserving the memory of the early

Church from which it sprung. According to the Kirtland Historic Center,

Using local sandstone and native timber from surrounding forests, the people worked together to construct what was then one of the largest buildings in northern Ohio. The Kirtland Temple stood at the center of community life for more than 2,000 believers by 1838 . Within a year, all but 100 were gone. ${ }^{39}$

The Kirtland community was a relatively brief and transitory midway point between

Missouri and Nauvoo, which is of more concern to the discussion at hand. The Kirtland

Historic Center, run by the Community of Christ, attributes the downfall of the Kirtland

community largely to banking troubles,

Shortly after the dedication of the temple, the community fell on difficult times. Financial and personal tensions rose between members of the church and with surrounding communities. Much of the tension was caused from the creation of a bank, known as the Kirtland Safety Society AntiBanking Company. This bank, located a few yards from the temple, was opened with hopes of alleviating the economic stresses of the community. Without a charter, the bank quickly lost the support of the surrounding communities and failed within months of opening. Lawsuits and dissent related to the failure of the Kirtland Bank resulted in the breakup of the community in 1838. By 1839 , the Latter Day Saint community consisted of only 100 members.

Many Kirtland residents moved first to northern Missouri and then to Nauvoo, Illinois. Despite the frequent moves the church grew quickly and the teachings of its leaders evolved rapidly. Political, economic and religious differences with neighbors led to conflict, resulting in the death of Joseph Smith Jr. in $1844 .^{40}$

As indicated by this excerpt, after a brief, troubled stay in Kirtland, scores of Mormons

fled to territories in Missouri and then to Nauvoo, Illinois. According to Smith, divine

revelation dictated that the New Zion should be constructed in Independence, Missouri:

"For the land of Zion shall be a seat and a place to receive and do all these things."41

\footnotetext{
${ }^{38}$ Community of Christ, commonly referred to as the Reorganized Church of Jesus Christ of Latter Day Saints, formed after the death of Joseph Smith, Jr. out of a dispute over leadership and doctrine. The RLDS Church remains committed to preserving the history of the early LDS Church.

39 "Kirtland Temple History," Kirtland Temple Historic Center, http:/www.kirtlandtemple.org/history.html

40 "Kirtland Temple History," Kirtland Temple Historic Center, http://www.kirtlandtemple.org/history.html.

${ }^{41}$ Doctrine and Covenants 69:6.
} 
And thus saith the Lord your God, if you will receive wisdom here is wisdom. Behold, the place which is now called Independence is the center place; and a spot for the temple is lying westward, upon a lot which is not far from the courthouse. ${ }^{42}$

Smith's divine mandates directed the Saints as to their goals in Missouri,

Which city shall be built, beginning at the temple lot, which is appointed by the finger of the Lord, in the western boundaries of the State of Missouri, and dedicated by the hand of Joseph Smith, Jun., and others with whom the Lord was well pleased. ${ }^{43}$

During their years in Missouri, the Saints resumed community building and continued to experience conflict with neighbors. In 1838 , tensions escalated between Mormons and the "old settlers" in Missouri. Thousands of Mormons had been pouring in to Missouri, creating communities and acquiring land and power for the Church. This upset the old settlers and prompted much agitation among them. Details and interpretations of this period of conflict vary.

Stephen LeSueur places the rioting and violence between Mormons and nonMormons in the context of 1830 's Jacksonian democracy and its "majority rule" model. ${ }^{44}$ The old settlers felt that their voices represented the majority, and that the Mormons, with their anti-democratic, hierarchical religious communities, were the outsiders to be expelled. Of the grievances drawn up against Mormons by the old settlers, "We are daily told...that we, (the Gentiles) of this county are to be cut off, and our lands appropriated by [the Mormons] for inheritances. ${ }^{, 45}$ Religious or doctrinal issues concerned the old

${ }^{42}$ Doctrine and Covenants 57:3.

${ }^{43}$ Doctrine and Covenants $84: 3$.

${ }^{44}$ See Stephen C. Lesueur, The 1838 Mormon War in Missouri (Columbia, MO: University of Missouri Press, 1990).

${ }^{45}$ Richard Abanes, One Nation Under Gods: A History of the Mormon Church (New York: Thunder's Mouth Press, 2003), 104. 
settlers as surely as did the economic and political issues of a new and burgeoning bloc of ultra-religious voters with charismatic and authoritative leadership.

In 1838-9, Governor Lilburn Boggs issued an "extermination order," whereby "8,000 to 10,000 Mormons were driven out of Missouri. Boggs had declared Mormons in "open and avowed defiance" of state law, "and of having made war upon the people of Missouri." ${ }^{46}$ In October of 1838, Boggs declared, "The Mormons must be treated as enemies... and must be exterminated or driven from the State if necessary for the public peace; their outrages are beyond all description. ${ }^{, 47}$ The same year, a local militia savagely attacked a Mormon settlement at Haun's Mill with orders to "Shoot at everything wearing breaches, and shoot to kill." According to published reports, eighteen men and boys were killed in that assault. ${ }^{48}$

The Mormons were effectively evicted from Missouri during the winter of 183940. During this time, Smith was jailed for five months for allegedly resisting attack. While in jail, Smith wrote a letter to his wife, Emma, in which he expressed joy in persecution:

Brother Robison is chained next to me he has a true heart and a firm mind, Brother Whight, is next, Br. Rigdon, next, Hyram, next, Parely, next Amasa, next, and thus we are bound together in chains as well as cords of everlasting love, we are in good spirits and rejoice that we are counted worthy to be persicuted $[$ sic $]$ for christ $[$ sic $]$ sake. ${ }^{49}$

\footnotetext{
${ }^{46}$ Anna Scianna, "Missouri's Mormon past - Columbia Missourian," Columbia Missourian, http://www.columbiamissourian.com/stories/2006/10/15/missouris-mormon-past/.

${ }^{47}$ Robert Alan Goldberg, Enemies Within: The Culture of Conspiracy in Modern America (New Haven: Yale University Press, 2001), 7.

${ }^{48}$ Will Bagley, Blood of the Prophets: Brigham Young and the Massacre at Mountain Meadows (Norman: University of Oklahoma Press, 2004), 12.

${ }^{49}$ Richard Lyman Bushman, "Joseph Smith's Place in History: A Biographical Foreword," The Joseph Smith Papers, josephsmithpapers.org/Essays/Bushman.pdf.
} 
Violence sprang from both sides, and the extent to which Mormons adopted defensive violence is problematic; ${ }^{50}$ however, it is clear that in the case of the 1838 Mormon War, the Church and its people were forcibly expelled from Missouri due to violent conflict. The ways in which these events were construed by the Church in the following years was guided by Smith and his ongoing revelations in the newly formed community of Nauvoo, Illinois.

In early 1839 , approximately five thousand Mormons settled into Hancock County, Illinois, ${ }^{51}$ having been ejected from Missouri. Smith named the new community "Nauvoo", believing that this was a Hebrew word meaning, "the beautiful place." Missouri was to have been the site for the New Zion, where Jesus the Christ would personally reign on earth. The doctrine of the New Zion was not abandoned upon leaving Missouri, only put on hold for the world to come. The sanctity of Missouri was transported to Nauvoo with memories of persecution fresh in the minds of Mormon settlers.

Smith continued to receive revelations in Illinois; these public declarations corrected for any disappointment or confusion over their losses in Missouri. Smith proclaimed, "I have now a great proclamation for the Elders to teach the Church hereafter which is in relation to Zion. The whole of North and South America is Zion;" furthermore, Smith proclaimed, "any place where the Saints gather is Zion." 52 Smith

\footnotetext{
${ }^{50}$ See Stephen C. Lesueur, The 1838 Mormon War in Missouri (Columbia, MO: University of Missouri Press, 1990).

${ }^{51}$ Robert Flanders, Nawvoo: Kingdom on the Mississippi (Urbana: University of Illinois Press, 1975), 1.

${ }^{52}$ Grant Underwood, The Millenarian World of Early Mormonism (Urbana: University of Illinois Press, 1993), 34 .
} 
affirmed to his flock that the losses suffered in Missouri would be justified, and the Saints were to carry on:

And this I make an example unto you, for your consolation concerning all those who have been commanded to do a work and have been hindered by the hands of their enemies, and by oppression, saith the Lord your God. For I am the Lord your God, and will save all those of your brethren who have been pure in heart, and have been slain in the land of Missouri, saith the Lord. ${ }^{53}$

The shift in focus from Missouri to Illinois as the center of Mormon religious and economic activity was one of many dramatic, revelatory shifts that would follow in Mormon perception of self, land, and doctrine. ${ }^{54}$ Under Smith's leadership, Nauvoo was molded into an idyllic Mormon community-- insulated, with a central church authority guided by living prophets receiving modern revelations. The Church and community at Nauvoo, with its temple building, secretive rituals, strange practices, claims of ongoing revelation, and tightly controlled theocratic government, yet again were perceived as a threat to neighboring peoples and to American values of democracy and individuality. Initially, Mormons were welcomed to Illinois and granted a city charter for Nauvoo; however this warm reception was short-lived. The growing Mormon community welcomed converts from Europe and Mormons from all over the country. It was at Nauvoo that anti-Mormon rhetoric and violent persecution came to a peak with the death of Joseph Smith in a series of incidents that would later become integral to Mormon history, identity, and theology. During their time in Nauvoo, hierarchical authority and the power of ongoing revelation were a major focus of activity, much to the chagrin of neighbors.

\footnotetext{
${ }^{53}$ Doctrine and Covenants 124: 53-4.

${ }^{54}$ One of the most well-known of these "shifts" concerned polygamy in the late nineteenth century; others include inclusion of 'blacks' into the priesthood in the $20^{\text {th }}$ century, and a large-scale, global missionary focus during the twentieth and early twenty-first centuries. The global shift especially has been significant in its impact on perceptions of sacred land.
} 
A strong hierarchical authority structure is not unique to Mormonism, but the authoritative nature of ongoing revelation and the way in which this system has worked to help the Church to adapt to changing times is an important component of how Mormons see themselves and how they are seen by Americans. In contrast to their more traditional Christians neighbors, whose faith taught that Jesus Christ was the final and complete self-revelation of God, Mormons believed that revelation was ongoing and given directly to their Prophet, Joseph Smith.

By the time the Saints entered Nauvoo, memories of persecution and a distinct identity were firmly in place, yet Smith was not content and he continued to novelize his church, making it even more distinct from other Christian sects. It was in Nauvoo that Smith introduced some of the most peculiar aspects of Mormon theology, such as the doctrine of the plurality of gods, baptism for the dead, eternal marriage rites, and plural marriage. ${ }^{55}$ The secretive temple rituals were also established in Nauvoo, borrowing from Masonic rites. Historian R. Laurence Moore argues that Smith's "strategy of secrecy" worked to provide a distinct sense of identity, as a people set apart, for his followers.

In Nauvoo as in other communities, Mormons published and were the subject of publications by outsiders. The Evening and the Morning Star was "a monthly newspaper commissioned to announce salvation 'before the great and terrible day of the Lord'." These early publishing efforts were a sort of public narrative, a conversation about who the Mormons were-internally and as perceived by others. However, this public exchange

\footnotetext{
${ }^{55}$ Leonard J. Arrington and Davis Bitton, The Mormon Experience: A History of the Latter-Day Saints (Urbana: University of Illinois Press, 1992), 69; R. Laurence Moore, Religious Outsiders and the Making of Americans (New York: Oxford University Press, 1986), 36.

${ }^{56}$ Richard Abanes. One Nation Under Gods: A History of the Mormon Church (New York: Thunder's Mouth Press, 2003), 103.
} 
left an unrestricted space for anti-Mormon rhetoric and propaganda to flourish. ${ }^{57}$ In 1842 , divinity professor Henry Caswell published The City of the Mormons; Or Three Days at Nauvoo, in which he labeled Mormons heretics along with "Jews, Turks," and "infidels." Caswell writes in his preface:

The following narrative... is presented to the Christian public, with a deep sense, on the author's part, of the iniquity of an imposter, which, under the name of religion, is spreading extensively in America...Mormonism needs to be seen in its true light to be hated.

Caswell goes on to state that if his testimony "should assist in awakening public indignation against a cruel delusion and a preposterous heresy, he will consider himself aptly rewarded." ${ }^{58}$ Clearly, Caswell's target audience was the majority Christian population, and his stated goal was to fan the flames of anti-Mormon rhetoric. Caswell points out to his Christian readers that any new religion is by default an imposter against the one true church, and especially in the case of the Mormons, "who believe themselves surrounded by the full blaze of prophecy and miracle." 59

Dissenters from within, divided over Smith's revelations regarding plural marriage and branded apostates by Smith, established the Nauvoo Expositor in 1844 . Publishers were listed as William Law, Wilson Law, Charles Ivins, Francis M. Higbee,

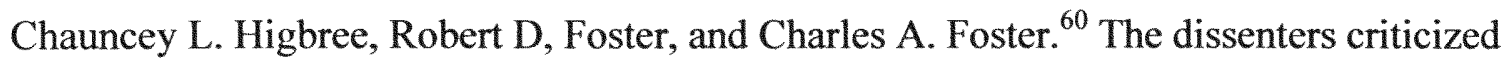
Smith for the introduction of plural marriage into Church doctrine and for his unmitigated

\footnotetext{
${ }^{57}$ R. Laurence Moore, Religious Outsiders and the Making of Americans (New York: Oxford University Press, 1986), 37.

${ }^{58}$ Henry Caswall, "City of the Mormons, 1842," Joseph Smith's History Vault, Archives, olivercowdery.com/smithhome/1840s/1842Cas1.htm, preface.

${ }^{59}$ Henry Caswall, "City of the Mormons, 1842," Joseph Smith's History Vault, Archives, http://olivercowdery.com/smithhome/1840s/1842Cas1.htm, preface.

60 s"1844 Nauvoo Expositor newspaper: pages 1-2," Early Mormonism Collection 2, http://solomonspalding.com/docs/expositl htm\#pglclb.
} 
power over the city. Only one issue of the Expositor was published, after which it was famously sanctioned for destruction by Smith and the city council of Nauvoo. The paper's press was destroyed by the Nauvoo Legion three days after the release of its first and only issue, signaling the "beginning of the end" for the early founding period of Mormonism. ${ }^{61}$

Anti-Mormons opposed Nauvoo's "fusion of church and state... its flouting of due process...[and] its bald outrage against the freedom of the press." ${ }^{.62}$ Smith fled to nearby Carthage, where Illinois Governor Thomas Ford sought him out, asking that he face the charges against him in order to avoid increasing conflict and potential mob violence. Initially, Smith and his brother, Hyrum, thought to flee Illinois. However, messengers carried word to Smith about the state of his flock; frightened and without their leader, the Mormons would surely be scattered by their enemies. Governor Ford promised Smith's safety if he turned himself in, yet Smith was reported to have told his brother, "If you go back, I will go with you, but we shall be butchered." ${ }^{63}$ The tale of Smith's martyrdom is notorious. Smith agreed to be jailed in Carthage and transported to Nauvoo under the condition that Governor Ford escort him there. Smith knew that if he was left alone and imprisoned in Carthage, that bloodthirsty militias would be his undoing. Three days later, Governor Ford rode to Nauvoo without Smith. Another three days later, an incensed mob dragged Smith from his jail cell and shot him in the street. ${ }^{64}$

\footnotetext{
${ }^{61}$ Roger D. Launius and John E. Hallwas, Kingdom on the Mississippi Revisited: NAUVOO IN MORMON HISTORY (Urbana: University of Illinois Press, 1996), 57-8.

${ }^{62}$ Wallace Stegner, Mormon Country (Toronto, Canada: Bison Books, 2003), 28.

${ }^{63}$ Wallace Stegner, Mormon Country (Toronto, Canada: Bison Books, 2003 ), 29.
} 
Smith's death set the stage for the second phase of the foundational period. His martyrdom sealed his place as founder, leader, and prophet of a church and a people whose identity had been forged in persecutions and conflict--an identity of otherness.

As Goldberg ${ }^{65}$ and others have noted, it was not simply the Mormons' fervent and peculiar theology, but their commitment to bloc-voting and the pooling of financial resources that cast Mormons as a threat to the American experiment. Social as well as theological differences contributed to apprehension generated around the Saints. In Nauvoo, as in Missouri and other settlements, the Mormons constructed an insulated, theocratic society, contradicting the popular notion of separation of Church and State at a time when the nation was attempting to distance itself from church run government, especially novel and unconventional religious movements. Smith demanded total obedience of his flock to Church authority, posing a threat to democracy as Mormon communities gained in size and land holdings.

In 1844 , shortly after Smith's death, Brigham Young led the majority of the Mormon community out of Nauvoo and westward to the Salt Lake Valley. The trek across the rugged American terrain is the stuff of legend-the Mormon Trail is customary reading for American public high school students and a significant element of American history. For Mormons, it is the sacred history of an elect and persecuted people expelled from their promised lands, a westward exodus across the sacred landscape of the United States. In 1844-47, Young led the Nauvoo Mormons to the Great Salt Lake Valley. Under Young's leadership, the structure and practice of Mormonism underwent growth and

\footnotetext{
${ }^{64}$ Wallace Stegner, Mormon Country (Toronto, Canada: Bison Books, 2003 ), 29.

${ }^{65}$ See Robert Alan Goldberg, Enemies Within: The Culture of Conspiracy in Modern America (New Haven: Yale University Press, 2001).
} 
some significant transformations; however, the theme of conflict continued to play a role

in Mormon identity formation for the remainder of the nineteenth century.

Establishing themselves as the dominant force in the mountains and deserts of the Great Basin, the Mormons soon came into direct conflict with the federal government over the issues of theocratic rule and the practice of polygamy...this struggle continued... until, under relentless government pressure, the Mormon Church finally gave in, relinquishing political power to the federal government, economic control of the Great Basin region to the national corporate economy, and the practice of plural marriage to the "limbo of theological relics. ${ }^{66}$

A major source of conflict stemmed from the practice of plural marriage ${ }^{67}$; the issue of slavery divided the nation, but Americans were united in their opposition to plural marriage. Although never practiced by all or even most Mormons, during the last half of the nineteenth century, there was a general belief among Mormons that polygyny in particular was "a social law, a truth revealed from heaven," "a prescription for health, an antidote for immorality, and a key to history and government." ${ }^{.68}$ The nation, however, remained intolerant of this practice. Utah Mormons and the issue of polygamy became the concern of the nation through the popular press, as noted extensively by Eliason and others:

The highly literate American public developed a strong appetite for Mormon fare. As the popular press rediscovered the Mormons in Utah, several modes of highly charged writing about Latterday Saint polygamy emerged. Most of the text generated about polygamy fell into two opposing camps. Both camps contended that the persuasiveness of their rhetoric held dire political stakes for the nation. One camp was composed almost completely of Mormons and lauded the social benefits and scriptural soundness of the practice while advocating a broad view of American religious liberty. The other camp, composed of popular novelists, religious leaders, and social reformers, decried polygamy in the harshest possible terms as a theological heresy and a gross degradation of true womanhood. Such writers spared no epithets in denouncing polygamy's sponsoring

\footnotetext{
${ }^{66}$ Gordon Shepherd and Gary Shepherd, "Mormonism in Secular Society: Changing Patterns of Ecclesiastical Rhetoric," Review of Religious Research 26 (1984), 30.

${ }^{67}$ Note on terminology: the term polygamy is used often when referring to the practice of plural marriage by Mormons in the $19^{\text {th }}$ century. Polygyny, the practice of multiple wives to one husband, is a more precise term here.

${ }^{68}$ B. Carmon Hardy, Solemn Covenant: The Mormon Polygamous Passage, (Urbana: University of Illinois Press, 1992), xviii.
} 
institution. Despite earnest efforts, Mormon defenders were outnumbered and out-paged in the debate. ${ }^{69}$

In 1856, the Republican Party, influenced by The Mormon Question, introduced into its platform "a resolution asserting that it was the right and duty of congress "to prohibit in the Territories those twin relics of barbarism-Polygamy and Slavery.",70 The Mormon Question put a central focus on polygamy and "the Defacto and unchecked political independence of the Mormon Church in Utah territory." 71

One year after publication of The Mormon Question, an event took place that would not be brought to the public for two more years. In an 1859 issue of Harper's Weekly, U.S. Army Surgeon Charles Brewer shared his experiences and interpretations of the event after a visit to the site. Brewer called the events of 1857 , which would later be dubbed The Mountain Meadows Massacre, the "crime of the century." 72 The story of the Mountain Meadows Massacred "scandalized the nation for decades", however, as Will Bagley reminds us, "the...truth of this American drama is elusive." 73 The basic events of The Mountain Meadows Massacre are as follows:

a party of emigrants from Arkansas attempted to take the southern route from Great Salt Lake City to California in September, 1857, and-except for eighteen young children-were murdered by members of a Mormon militia unit and their Indian allies. ${ }^{74}$

\footnotetext{
${ }^{69}$ Eric A. Eliason, "Curious Gentiles and Representational Authority in the City of the Saints," Religion and American Culture 11 (2001): 156.

${ }^{70}$ Richard H. Cracroft, "The Assault on Laughter: The Comic Attack on Mormon Polygamy in Popular Literature," Journal of Mormon History 34 (2008): 234.

${ }^{71}$ Richard H. Cracroft, "The Assault on Laughter: The Comic Attack on Mormon Polygamy in Popular Literature," Journal of Mormon History 34 (2008): 234.

${ }^{72}$ Will Bagley, Blood of the Prophets: Brigham Young and the Massacre at Mountain Meadows (Norman: University of Oklahoma Press, 2004), xiii.

${ }^{73}$ Will Bagley, Blood of the Prophets: Brigham Young and the Massacre at Mountain Meadows (Norman: University of Oklahoma Press, 2004), xiii.
} 
The events of 1857 marked the culmination of a period of conflict between Mormons and outsiders, fueled by vigilante, extremist militia and mob groups on both sides. The effect of the Mountain Meadows Massacre on American public perception seems to have generally died down by 1860 . Jan Shipps found that "between 1860-1870, American perceptions of Mormons shifted from "extremely negative" to "neutral", partly due to the nation's diverted attention to the contested issue of slavery around $1861 .^{75}$ (In 1896, Utah was at last granted statehood and admitted into the Union, having denounced polygamy and set out on the road toward assimilation. It is still debated what role the cessation of polygamy from Mormon public life played in the more favorable public perceptions of Mormons afterwards, but clearly it played a significant role, if only symbolically).

Throughout the remainder of the nineteenth century, Mormons continued to captivate the nation's attention, and as conflict decreased, criticism, inquiry, and humor set in. Mark Twain's Mysterious Stranger quipped, "Against the assault of laughter, nothing can stand," ${ }^{76}$ in reference to "the effect of mockery in reducing cherished human institutions to rubble. ${ }^{, 77}$ In his 1872 semi-autobiographical tale of his travels across the American West, Roughing It, Twain wrote of the Book of Mormon, "The book seems to be merely a prosy detail of imaginary history, with the Old Testament for a model;

\footnotetext{
${ }^{74}$ Jan Shipps in Juanita Brooks, The Mountain Meadows Massacre (Norman: University of Oklahoma Press, 1991), vi.

${ }^{75}$ Jan Shipps, Sojourner in the Promised Land: Forty Years Among the Mormons (Chicago: University of Illinois Press, 2000), 62.

${ }^{76}$ Mark Twain, The Mysterious Stranger (New York: Viking Press, 1946), 716.

${ }^{77}$ Richard H. Cracroft, "The Assault on Laughter: The Comic Attack on Mormon Polygamy in Popular Literature," Journal of Mormon History 34 (2008): 237.
} 
followed by the tedious plagiarism of the New Testament." ${ }^{78}$ Twain and other notable

Americans like Abraham Lincoln admired and were influenced by American humorist

Charles Farrer Brown, better known as Artemus Ward. ${ }^{79}$ Ward's "antipolygamist

comedy," beginning in the $1860 \mathrm{~s}$, consisted of extreme exaggerations about the state of

polygamy in Utah. Ward joked of Brigham Young's "eighty wives" and Heber C.

Kimball's "hundred head of wives." 80

In his 1881 inaugural address, President James Garfield denounced polygamy:

The Mormon Church not only offends the moral sense of manhood by sanctioning polygamy, but prevents the administration of justice through ordinary instrumentalities of law. In my judgment it is the duty of Congress, while respecting to the uttermost the conscientious convictions and religious scruples of every citizen, to prohibit within its jurisdiction all criminal practices, especially of that class which destroy the family relations and endanger social order. Nor can any ecclesiastical organization be safely permitted to usurp in the smallest degree the functions and powers of the National Government. ${ }^{81}$

For Mormons, "plural marriage was a divine commandment received through revelation to Joseph Smith their prophet-a recapitulation of the familial practices of righteous biblical patriarchs". Americans strongly opposed polygamy as an "un-Christian abomination, a threat to traditional marriage customs, and just the sort of scandalous thing they loved to read about.".82

\footnotetext{
${ }^{78}$ Mark Twain, Roughing It (New York: Harper And Brothers, 1913), 110.

${ }^{79}$ Richard H. Cracroft, "The Assault on Laughter: The Comic Attack on Mormon Polygamy in Popular Literature," Journal of Mormon History 34 (2008): 240.

${ }^{80}$ Richard H. Cracroft, "The Assault on Laughter: The Comic Attack on Mormon Polygamy in Popular Literature," Journal of Mormon History 34 (2008): 243.

81 "James Abram Garfield: Inaugural address, Friday, March 4, 1881," From Revolution to Reconstruction, www.let.rug.nl/usa/P/jg20/speeches/garfield.htm.

${ }^{82}$ Eric A. Eliason, "Curious Gentiles and Representational Authority in the City of the Saints," Religion and American Culture 11 (2001): 156.
} 
Nine years after Garfield publically condemned polygamy, Church President Wilford Woodruff released his famous Manifesto, officially denouncing the practice of plural marriage by members of the Church of Jesus Christ of Latter-day Saints. Woodruff cited the manifesto as a result of "the loud, vigorous, and sustained "opposition of sixty millions of people." $" 83$

Americans perceptions of Mormons declined from 1870 - 1885, after which perceptions began to rise again toward a more positive image. The period between 1880 and 1890 was one of the most difficult in Mormon history. During this time, the Church and its principles stood at odds not with local settlers or angry mobs, but with the entire nation, mainly over the issues of polygamy and Utah statehood. After 1890, with the issues of statehood and polygamy generally put to rest, Mormon ranks began to grow again after a period of decline. ${ }^{84}$

By 1895 , five years after the official and public cessation of Church sanctioned plural marriage, public perception was as its highest ever, somewhere between "slightly positive" and "fairly positive." 85 Ellsworth notes that by the end of World War I, Mormons were "well accepted by the people of the nation." polygamy came a new phase of Mormon history-a time of growing assimilation. In his survey of Utah and Mormon history, S. George Ellsworth "described the years between

\footnotetext{
${ }^{83}$ Richard H. Cracroft, "The Assault on Laughter: The Comic Attack on Mormon Polygamy in Popular Literature," Journal of Mormon History 34 (2008): 236.

${ }^{84}$ Stark, Rodney. "So Far, So Good: A Brief Assessment of Mormon Membership Projections." Review of Religious Research 38 (1996): 177.

${ }^{85}$ Jan Shipps, Sojourner in the Promised Land: Forty Years Among the Mormons (Chicago: University of Illinois Press, 2000), 63.

${ }^{86}$ Jan Shipps, Sojourner in the Promised Land: Forty Years Among the Mormons (Chicago: University of Illinois Press, 2000), 66.
} 
1896 and 1929 as years of transition from the pioneer to the modern world," adding that "the antagonism of the territorial period died slowly."

During the foundational period, the Church and its growing population stood, to a certain extent, at odds with the American public. Americans who came into contact with Mormons and their communities generally viewed them as outsiders, as a curiosity, and at worst, as heretical and cult-like. However, by the turn of the century, the Church was an organized, rational institutional, integrated into American society. 


\section{Toward Assimilation and Modernization, 1900-1960s}

The first half of the twentieth century was a time of assimilation and modernization for the Church in Utah and elsewhere. Americans' perceptions of Mormons during this time were generally more favorable than in the past. Mainstream Mormonism no longer sanctioned polygamy, and its millenarian aspects were downplayed, as is common with institutions as they move along the sect-to-church continuum. The strangeness and otherness of Mormons and their communities no longer dominated the public imagination as the Church became modernized and Americanized, and emphasized its Christian elements. A shift away from conflict toward modernization characterizes this period.

During the early years of the twentieth century, a shift in the nation's attitude toward Mormons and Mormonism occurred. Americans and Europeans were curious about the Mormons, a tightly-knit religious community originating in America and spreading to other nations. In 1903, Richard T. Ely pronounced "the organization of the Mormons" to be "the most nearly perfect piece of social mechanism" that he had come into contact with since the German Army ${ }^{87}$ Just as in the latter half of the previous century, Mormons were generally perceived as "theocratic and cooperative," however this was perceived of more as a curiosity than a threat. Ely also noted the high degree of assimilation to American life that was evident among American Mormons. ${ }^{88}$

\footnotetext{
${ }^{87}$ Rodney Stark and Reid L. Neilson, The Rise of Mormonism (Columbia: Columbia University Press, 2005), 28.

${ }^{88}$ Armand L. Mauss, "Sociological Perspectives on the Mormon Subculture," Annual Review of Sociology 10 (1984): 438.
} 
Early American folklore and public humor contributed to the ways Mormons viewed and talked about themselves and the way Americans perceived Mormons. As Mormons became more modernized, along with the rest of the growing nation, public figures somewhat took over the function of mythic heroes in past societies. Early Americans had their public heroes surrounded by folklore, such as Thomas Jefferson and Abraham Lincoln, and so did the Church. Under the guidance of Elder J. Golden Kimball $^{89}$ (1853-1938), a charismatic folk hero of the Church, Mormons were better able to express amusement at their own eccentricities. Elder J.G. Kimball was "one of the first of a new generation of Mormons to be born in the Utah Territory after the great trek west from Nauvoo, Illinois.. ${ }^{90}$ His father, "along with Brigham Young, was one of only two of the original apostles of The Church of Jesus Christ of Latter-day Saints to never waver from total loyalty to Joseph Smith, a fact surely impressed upon young Golden as he was growing up." ${ }^{91}$ Kimball was deeply devoted to the Church, and when his rugged character created rifts with Church authority, he fervently repented. Kimball was a beloved and charismatic figure often called "the Will Rogers of the Church" 92 for his ability to capture the attention of an audience. ${ }^{93}$

\footnotetext{
${ }^{89}$ Not to be confused with Heber C. Kimball, an early Church leader, or with Spencer Kimball, President of the Church from $1973-1985$.

${ }^{90}$ Eric A. Eliason, "Meridian Magazine: The Life and Lore of J. Golden Kimball - Mormon Folk Hero," Meridian Magazine, http://www.meridianmagazine.com/arts/070927kimball.html.

${ }^{91}$ Eric A. Eliason, "The Life and Lore of J. Golden Kimball - Mormon Folk Hero," Meridian Magazine, http://www.meridianmagazine.com/arts/070927kimball.html\#_ednref2.

92 Claude Richards, J. Golden Kimball: The Story of a Unique Personality (Salt Lake City: Deseret News Press, 1966, originally published 1934), 123.

${ }^{93}$ Wallace Stegner, Mormon Country (Toronto: Bison Books, 2003), 190.
} 
Folktales about Kimball abound in Utah, dealing with topics from his penchant for "cursing" to poking fun at Church authority. One popular tale about Kimball recounts an incident in which Kimball is having a meal in a restaurant in the company of lawyers and others. Kimball, like all good Mormons, was forbidden to drink tea or coffee, though he was known to be fond of coffee. It is said that when the waiter solicited his drink order, Kimball meekly muttered "water." An associate at the table said to the waiter, "Oh, bring him coffee. He likes coffee." Upon receiving the coffee, Kimball is said to have jested, "The Lord heard me say water." 94 On another occasion, Kimball is said to have responded to Senator Reed Smoot's upcoming marriage to a young lady named "Sister Sheets" with, "You're a pretty old man, you know. And Sister Sheets, she's a pretty young woman. And she'll expect more from you than the laying of hands." ${ }^{95}$ Kimball's "iconoclastic wit and biting sense of humor... helped [Mormons] to see a lighter side of their often difficult existence,"996 his popular influence brought humor and elements of rugged heroism, popular in early America, to Mormonism.

For a brief time because of World War I, "with all travel abroad curtailed, Mormon growth slowed slightly between 1910 and 1920" and actual membership fell." 97 The successive Great Depression and World War II slowed Mormon growth, yet growth

\footnotetext{
${ }^{94}$ Richard M. Dorson, Buying the Wind: Regional Folklore in the United States, (Chicago: University Of Chicago Press, 1972), 514.

${ }^{95}$ Richard M. Dorson, Buying the Wind: Regional Folklore in the United States, (Chicago: University Of Chicago Press, 1972), 121.

${ }^{96}$ Daniel H. Ludlow, "Encyclopedia of Mormonism," Harold B. Lee Library, http://contentdm.lib.byu.edu/u?/EoM,3781.

${ }^{97}$ Rodney Stark, "So Far, So Good: A Brief Assessment of Mormon Membership Projections," Review of Religious Research 38 (1996): 177.
} 
did continue during these times. ${ }^{98}$ Brigham Young and the leadership following him emphasized a gathering of Saints to Zion-Salt Lake City, Utah. Around the 1920s, the ideal of gathering up of the Saints in one physical location began to change to an emphasis on creating Zion wherever Saints were found. Mormons were encouraged to spread out over the United States and missionaries were sent out internationally. Consequently, in the 1920s and 30s, Mormons began to move to larger cities in the west and Midwest, many seeking better economic and educational opportunities. ${ }^{99}$ During this time, Mormons spread across the continent and around the world; "mini-Zions" were set up with social and administrative ties to Church headquarters in Utah. ${ }^{100}$

Up until World War II, the Salt Lake City Mormons were primarily an agrarian society, but with the War came drastic changes:

The war brought the same disruptions to Mormon society that it brought to the rest of America, pulling people off farms into higher paying jobs in industrial areas and in centers of population. As a result, most Mormons now live in cities and have embraced the changes and the mobility of contemporary American life as eagerly as their fellow citizens-most of them, in outward appearance at least, seem little different from other modern urbanites. ${ }^{101}$

Jan Shipps notes that "historians have long known that there was a dramatic shift in the way Americans imagined the Saints in the middle of the nineteenth century and... a century later."102 In 1947, Time magazine published an article entitled, "A Peculiar

\footnotetext{
${ }^{98}$ Rodney Stark, "So Far, So Good: A Brief Assessment of Mormon Membership Projections," Review of Religious Research 38 (1996): 177.

${ }^{99}$ Benjamin H. Johnson, Making of the American West: People and Perspectives, (Santa Barbara, CA: ABC-CLIO, 2007), 131-2.

${ }^{100}$ Marie Cornwall, Tim B. Heaton, and Lawrence A. Young, Contemporary Mormonism: Social Science Perspectives, (Urbana: University of Illinois Press, 2001), 76.

${ }^{101}$ William A. Wilson, "Mormon Narratives: The Lore of Faith,” Western Folklore 54 (1995): 304.

102 Jan Shipps, Sojourner in the Promised Land: Forty Years Among the Mormons (Chicago: University of Illinois Press, 2000), 46-7.
} 
People." The article, inspired by the 100th anniversary of the westward trek from Nauvoo to Salt Lake City, refers to the Church at mid-twentieth century as a "self-made oasis on the Western desert... flourishing like a green bay tree." 103 In commemoration of the Mormon trail, 143 men, women, and children set out from Nauvoo to Salt Lake City, "their shiny new Buick and Studebaker automobiles...disguised by plywood oxen and white canvas tops." The article claims that the commemorators "camped out every night" to please the church's publicity department." 104 The implication was that by midtwentieth century, the Church and its people were prosperous and thriving within American society. By this time, the threat of violent conflict was all but non-existent, and Mormons were in a place where the conflicts of the past could be incorporated into a communal Mormon sense of identity as a people and a Church. The centennial commemorative event created a link to the past, a living symbol of the "collective memory" 105 of a religious community. The collective memory of a people is transmitted through sacred space and story, and in this process, identity is strengthened. This is a process that will continue to unfold throughout the nineteenth and into the twentieth centuries.

Popular periodicals during this time generally cast Mormons in a positive light. With a readership of over 16 million during the 1940s and 50s, Reader's Digest held a powerful and influential position in the public sphere. Reader's Digest published "They

${ }^{103}$ George Albert Smith, "A Peculiar People," TIME.com (1947), http://www.time.com/time/magazine/article/0,9171,779210,00.html.

${ }^{104}$ George Albert Smith, “A Peculiar People,” TIME.com (1947), http:/www.time.com/time/magazine/article/0,9171,779210,00.html.

${ }^{105}$ As an abstract concept, collective memory can be said to encompass the shared, communal memory (whether factual-historical or otherwise) of a people. In other words, the 'memory' of a people is its history as understood by those people. 
powerful and influential position in the public sphere. Reader's Digest published "They Take Care of Their Own" in 1949 and "The Mormons: A Complete Way of Life" in 1955. Jan Shipps notes that articles such as these emphasized "the self-sufficiency of the Saints," leading to a "mistaken perception that the Church Welfare Plan kept the entire LDS population off all governmental public assistance programs." ${ }^{\prime 106}$ Americans' perceptions of Mormons rose fairly steadily from 1920 to $1960 ;{ }^{107}$ the popular media played an important role in this shifting of perceptions. Assimilation and modernization continued into the 1950s. With the country on the mend and turning toward so-called "conservative" values such as patriotism and the ideal of the nuclear family-with husband/father as the head of the home and breadwinner, and wife/mother as homemaker-Mormons, already embracing these values-were primed for acceptance.

In 1950 Juanita Brooks published her important work, The Mountain Meadows Massacre. As a practicing Latter-day Saint, Brooks laid bare her bias, yet promised an unbiased, truthful account of the events. All accounts of the Meadows Massacre have their critics, and much research has been done since the time of this account. Yet Brooks' work is still considered a classic and important account of the events of 1857 . Brooks' publication of her work in 1950 was no accident, the climate was right for a discussion of events which in the past had been deemed distasteful or threatening. The 1950s was an ideal time for the publication of Brooks' work:

Since the Mountain Meadows Massacre occurred... we [Mormons] have tried to blot out the affair from our history. It must not be referred to, much less discussed openly. Years ago, that might

\footnotetext{
${ }^{106}$ Jan Shipps, Sojourner in the Promised Land: Forty Years Among the Mormons, (Urbana: University of Illinois Press, 2006), 68.

${ }^{107}$ Jan Shipps, Sojourner in the Promised Land: Forty Years Among the Mormons, (Urbana: University of Illinois Press, 2006), 68.
} 
dispassionately, and to see it in its proper setting as a study of social psychology as well as of history. ${ }^{108}$

Mormons in the 1950s were a picture of popular American values of home and family. Church President David O. McKay said in 1953, "I know of no other place than home where more happiness can be found in this life. It is possible to make home a bit of heaven; indeed, I picture heaven to be a continuation of the ideal home." ${ }^{109}$ The idea of home as heaven is reflected in the doctrine of celestial family, the Mormon belief that the family united through temple rites is united spiritually and eternally. Given this belief, traditional marriage and family become divine mandates.

Besides the issue of race and the priesthood-an issue dealt with later in the 1960s and 70s-"all major institutional and doctrinal accommodations to mainstream America had been achieved." 110 By the 1950s and 60s, Mormons "still considered themselves peculiar because of belief in Joseph Smith's visions, the Book of Mormon, and living prophets, but the Church had attained a high degree of assimilation impossible in the nineteenth century." 111

In the 1950 s, Mormons seemed to embody popular values of the time and earned the nation's positive appraisal. At this high point of assimilation and Americanization, we can see the very beginnings of a movement towards retrenchment, a pulling back towards

${ }^{108}$ Juanita Brooks, The Mountain Meadows Massacre (Norman: University of Oklahoma Press, 1991), xxv. ${ }^{109}$ Gospel Ideals, 1953, 490; "David O. McKay, 9th President of the Church," The Church of Jesus Christ of Latter-day Saints, http://www.lds.org/churchhistory/presidents/controllers/potcController.jsp?leader=9\&topic=facts.

${ }^{110}$ Claudia L. Bushman, Contemporary Mormonism: Latter-day Saints in Modern America (Westport, CT: Praeger Publishers, 2006), 183.

${ }^{111}$ Claudia L. Bushman, Contemporary Mormonism: Latter-day Saints in Modern America (Westport, CT: Praeger Publishers, 2006), 183. 
the maintenance of boundaries between insiders (Saints) and outsiders (Gentiles).

"Cultural peculiarities" such as ongoing prophecy by Church authorities, temple rituals, mission work, and the doctrine of celestial family all began to take center stage in a shared conception of Mormon identity. It was at this point that maintaining a distinct identity became crucial in order to avoid being completely assimilated into undifferentiated denominational uncertainty. The Church remained vital throughout this time, embracing conservative American values; however Church leadership recognized that the boundaries between Mormons and the outside world had to be redrawn and redressed in order for the Church to thrive in the next portion of the century and beyond. 


\section{Reclamation of Distinctiveness, 1960s-2000}

The 1960 s was a period of change for the entire nation, no less so for the Church of Jesus Christ of Latter-day Saints. Some of the major issues of this period mirrored those of the nation: civil rights, women's roles, and a social climate of change and protestation. The Church increasingly took control over its own public image throughout the Twentieth Century, emphasizing sobriety, industry, and piety. "The cooperative and communal economic experiments of nineteenth century Mormonism [were] displaced by a strong commitment to capitalism,"112 as well as an emphasis on Christian values. Mormons were generally perceived as a model of "conservative" values: family, industry, temperance, piety, all within a larger cohesive community. The lived experience of Mormons, as of all people, of course does not always precisely fit into the macro picture of Mormon identity, however a general trend leading from the preceding period to this one is that of two coinciding emphases: internal Church efforts to manage a positive public image, and a top-down effort to re-emphasize the more distinct features of Mormonism, both theologically and socially. Issues still troubling the Church, such as that of race and the priesthood and women's roles, would affect Mormon identity and the public's perceptions of Mormons, but eventually these issues were generally resolved and their impact healed. ${ }^{113}$

\footnotetext{
112 Armand L. Mauss and Philip Barlow, "Church, Sect, and Scripture: The Protestant Bible and Mormon Sectarian Retrenchment," Sociological Analysis 52 (1991): 401.

${ }^{113}$ Branch-off groups (such as RLDS) and extremist groups (militia and militant groups) also continued to play a role in the Church's public image, these groups however have no official connection with the mainstream Church of Jesus Christ of Latter-day Saints, and will be treated where appropriate.
} 
The image of the Church as a conservative American denomination, albeit a peculiar one, continued to be emphasized by the Church and perceived by outsiders throughout and after the 1960s; at the same time, however, the Church began to pull back towards distinctiveness. A slow and optimal level of tension began to develop between the Church as a religious and cultural group and the larger American society. As the century progressed, the Church and its people were no longer truly outsiders in America; tension between the host society and the Church had fallen to an unsurpassed low as perceptions reached record highs. Popular media covered the Church's "retrograde positive on race," yet more commonly Mormons were portrayed as "neat, modest, virtuous, family-loving, conservative, and patriotic people."114

Maintaining distinctiveness was a major challenge of this period, met by Church authority with a return to Mormonism's more distinctive doctrines. An emphasis on the Christ-centered nature of Mormonism, increased scholarly activity, and changes in official Church rhetoric all contributed to the new direction in Mormon identity and public perception that began in the 1960 s. ${ }^{115}$ "A new generation of leaders became concerned about the loss of the unique and 'peculiar' identity of the LDS Church", prompting Church leadership to institute "policy intended to increase the tension with

\footnotetext{
114 Jan Shipps, Sojourner in the Promised Land: Forty Years Among the Mormons (Urbana: University of Illinois Press, 2006), 100.

115 John Morehead, "Interview with Armand Mauss: Implications of Mormon Assimilation and Retrenchment," Morehead's Musings, http://johnwmorehead.blogspot.com/2008/01/armand-mauss-onangel-and-beehive.html.
} 
American culture, to move the Church back in the direction of 19 th century Mormonism in an effort to recover some of its lost "peculiarity' or identity."116

"That the Mormons were highly assimilated by the middle of the twentieth century" is demonstrated by a cursory glance at history, and more explicitly through the works of Mauss and others. ${ }^{117}$ While the Church emphasized a Christian image, "Evangelicals...chided Mormons for not really being Christians and not truly believing the Bible." 118 Even so, the Church navigated social issues along with the rest of the nation without harm to its public image.

In 1967, the Church celebrated its $137^{\text {th }}$ anniversary. That same year Time Magazine called the Church "the largest and strongest made-in-America faith." 119 The article applauds the Church's boom in membership: "Since 1940, membership in the church has more than tripled, to 2,600,000"; financial successes: "...Mormon-owned business enterprises-ranging from Utah's largest department store to a 360,000-acre Florida cattle ranch-help produce an income that some church observers estimate at $\$ 1,000,000$ per day"-and its ability to update and adapt doctrine; "much as in the churches of mainstream Christianity, Mormonism is being prodded out of its old ways by

\footnotetext{
${ }^{116}$ Morehead, John, "Interview with Armand Mauss: Implications of Mormon Assimilation and Retrenchment," Morehead's Musings. http://johnwmorehead.blogspot.com/2008/01/armand-mauss-onangel-and-beehive.html.

${ }^{117}$ Armand L. Mauss, The Angel and Beehive: The Mormon Struggle with Assimilation, (Urbana: University of Illinois Press, 1994), 60.

${ }^{118}$ Martin Johnson and Phil Mullins, "Mormonism: Catholic, Protestant, Different?," Review of Religious Research 34 (1992): 51.

119 "Prosperity \& Protest," TIME.com (1967), http://www.time.com/time/magazine/article/0,9171,836990,00.html.
} 
a new generation of believers who temper loyalty to the faith with a conviction that its doctrines need updating." 120

The Church has remained relevant through adaptation on many levels.

Theologically, the revelatory power of Church authority provides a means by which doctrine can be updated, while socially, a centrally organized global missionary campaign maintains global recruiting networks and outreach communities across the globe. Highly capable young single men and women are encouraged to serve approximately two-year periods of missionary work. While serving a mission, the missionary is "self-funded" by personal savings, family support, and community assistance. During this time, the missionary is intended to grow in faith and seek out moments of supernatural revelation. The missionary program saw a growth rate of 53 percent per decade from 1940 to $1980 .{ }^{121}$ Amidst all this growth, the Church continued to emphasize a clean-cut, All-American image, while simultaneously celebrating the theologically and socially distinct elements of Mormonism, such as the large-scale, even corporate, all-volunteer, missionary system.

The 1960s and 70s saw "increased engagement" between Church scholars and "the mainstream of academia," and open and scholarly discourse assisted in reducing any remaining "modern antiMormonism"122 by bringing the Church to the attention of mainstream academia. Increased scholarly activity focusing on Mormons' and

\footnotetext{
120 "Prosperity \& Protest," TIME.com (1967), http://www.time.com/time/magazine/article/0,9171,836990,00.html.

${ }^{121}$ Rodney Stark, "So Far, So Good: A Brief Assessment of Mormon Membership Projections," Review of Religious Research 38 (1996): 175.

122 John-Charles Duffy, "The Use of "Lamanite" in Official LDS Discourse," Journal of Mormon History 34 (2008): 148.
} 
Mormonism by "non-Mormon social historians and by a younger generation of Mormon social scientists more detached from the topic" ${ }^{123}$ continued into the 1970 s and 80 s and expanded sociological inquiry beyond studies of family and agriculture. Historians, sociologists, and scholars from many different fields weighed in on the question of the Mormons and their unique social structures, theology, and collective ideas about identity and community.

A problematic area for the Church during the late nineteenth century was the issue of race and the priesthood. Traditionally, the Mormon priesthood was open to all eligible white adult males, with women and non-whites barred from the position. The lifting of this ban for adult males only constituted a major ecclesiastical and doctrinal shift, accompanied by positive growth in the public's perceptions of Mormonism.

Both external and internal pressures contributed to the lifting of the ban on blacks in the priesthood. White and White discussed the significance of "environmental and organizational forces" such as unfavorable media publicity, "pressures from the black community, and threats of successful litigation." ${ }^{124}$ Internally, Church leadership strove towards growth and respectability, while Mormon intellectuals, activists, and blacks reinforced both the internal and external pressures. A year after White and White's study of the external pressures leading to the lifting of the ban on blacks in the priesthood, Mauss argued that internal pressures were "more impelling than...external pressures in

\footnotetext{
${ }^{123}$ Armand L. Mauss, "Sociological Perspectives on the Mormon Subculture," Annual Review of Sociology $10(1984), 439$.

${ }^{124}$ O. Kendall White, Jr and Daryl White, "Abandoning an Unpopular Policy: An Analysis of the Decision Granting the Mormon Priesthood to Blacks," Sociological Analysis 41 (1980): 231.
} 
explaining the priesthood policy change." 125

Another issue concerned the roles of women in the Church. Researchers have found that "despite initial resistance in the late 1960s and 1970s the Church has been moving to accommodate change in women's roles." Since at least the 1970 s, publicly the Church "has taken a position as protector of the 'traditional' heterosexual nuclear family." ${ }^{126}$ Historical scholarship has found that in earlier times, Mormon women shared with men the authority to bestow healings and blessings, yet by the mid twentieth century, spiritual authority in these matters were reserved for the male priesthood. ${ }^{127}$

The Book of Mormon is believed by church members to be an account of ancient ancestors of a tribe of Israelites who migrated to the North American continent. The early Church understood Native Americans to be descendents of this ancestor, Laman, and has worked steadily to convert them back into the fold throughout much of the twentieth

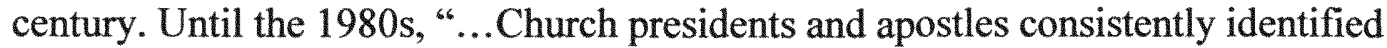
Lamanites as the literal ancestors of the native peoples of both American continents." Church President Spencer W. Kimball paid special attention to the Lamanite brethren, stating in 1972, "The growth of the Church is phenomenal. It relates to the Indians, to all the Lamanites, and to all the people of the world, for it has become a great and world church, when only yesterday it was a Utah church."128 However, after Kimball's passing

\footnotetext{
${ }^{125}$ Armand L. Mauss, "Comments: White on Black among the Mormons: A Critique of White \& White," Sociological Analysis 42 (1981): 277.

${ }^{126}$ Laura Vance, "Evolution of Ideals for Women in Mormon Periodicals, 1897-1999," Sociology of Religion 63 (2002): 91.

${ }^{127}$ Laura Vance, "Evolution of Ideals for Women in Mormon Periodicals, 1897-1999," Sociology of Religion 63 (2002): 91.
} 
in 1985 , "LDS discourse about bringing all people to Christ came to displace lineagecentered discourse regarding the gathering of Israel." ${ }^{129}$ Lamanite identification and rhetoric declined in official discourse" because it no longer served the purposes of promoting 'unity in a culturally diverse church' or emphasizing the 'Christian message. $"{ }^{\prime 130}$ Rather than focusing on identifying and converting Lamanites, the Church opened its arms with a global, universal missionary focus.

The Church at the end of the twentieth century was a religious, social, and cultural institution in its own right, secure in its place in America and increasingly, the world. The Church could now re-focus on the distinct and unique aspects of Mormonism. Mauss and Barlow point out that this retrenchment process presents an interesting problem to the otherwise generally predictable sect-church model. Rather than melting into pluralism or evolving into a "low tension church," 131 the Church again drew boundaries between insiders and outsiders, reminding Mormons and Gentiles alike that the Saints were a unique and distinct people, with a unique doctrine. Mauss defines the characteristics of the retrenchment process:

(1) A renewed emphasis upon certain unique sectarian teachings that had been downplayed earlier in the century, and which constitute heresies in the eyes of mainstream Christendom;

(2) A centralization and concentration of power in church governance;

(3) A renewed programmatic focus on traditional family roles, values, and organization;

(4) A greatly expanded and intensified daily religious education program for youth, with a demonstrably anti-intellectual orientation; and

\footnotetext{
128 "Church Growth and Lamanite Involvement - Spencer W. Kimball," Speeches (archives kept by Brigham Young University), http://speeches.byu.edu/reader/reader.php?id=6059.

129 John-Charles Duffy, "The Use of "Lamanite" in Official LDS Discourse." Journal of Mormon History 34 (2008): 148.

${ }^{130}$ John-Charles Duffy, "The Use of "Lamanite" in Official LDS Discourse." Journal of Mormon History 34 (2008): 165.
}

131 Armand L. Mauss and Philip Barlow, "Church, Sect, and Scripture: The Protestant Bible and Mormon Sectarian Retrenchment," Sociological Analysis 52 (1991): 402. 
(5) A growing trend at the grassroots toward a fundamentalist religious posture both in life-style and in scriptural interpretation, a posture condoned by some segments of the church leadership. ${ }^{132}$

A growing and changing Church within a changing society earned acceptance through modernization and accommodation, yet as the Twentieth Century progressed, the Church began to remember and emphasize its own distinctiveness at the risk of being swallowed into the denominational "melting pot." ${ }^{\text {133 }}$ Mormons were fairly well Americanized, and Americans were pleased to retain the "cherished myth of the melting pot"134 The Church strove to maintain a unique identity internally and a cohesive public image externally.

${ }^{132}$ Armand L. Mauss and Philip Barlow, "Church, Sect, and Scripture: The Protestant Bible and Mormon Sectarian Retrenchment," Sociological Analysis 52 (1991): 402.

${ }^{133}$ Will Herberg, Protestant-Catholic-Jew: An Essay in American Religious Sociology, (Chicago: University Of Chicago Press, 1983), 152.

${ }^{134}$ Marie Cornwall, Tim B. Heaton, and Lawrence A. Young, Contemporary Mormonism: Social Science Perspectives (Urbana: University of Illinois Press, 2001), 25. 
The Twenty-first Century finds the Church at a level of "optimum tension" with American society and with other Christian communities, where distinctiveness is maintained on each side of the boundary between self and other, and there is no great pressing concern or cause for hostility. The Church has moved along a curve of vitality from an early phase of fervor and activity, through assimilation and routinization, and most recently, a return to distinctiveness. The retrenchment process has included a backing away from the assimilation process on some level, and a continuation of it on another. Those elements unique to Mormonism such as Temple rites, celestial marriage, and other distinctive doctrines have been continually refreshed and re-emphasized since mid-twentieth century. The combination of renewal of distinctive beliefs and practices along with a continued modernization process have maintained the Church's prominent position in America's religious and cultural climate. Mormons are generally as thoroughly modern and American as any other group, yet a return to core doctrine and practices that took place during the last few decades of the twentieth century has created a unique place for the Church in the American religious landscape.

As of 2007, the Church claims a global membership of over 13 million members. ${ }^{135}$ A strong emphasis on missionary work, global outreach and the potent use of popular media such as the World Wide Web have all contributed to a greater acceptance of Mormons and the Church. The World Wide Web ${ }^{136}$ provides a forum for the instantaneous dissemination of information on a global scale. Communities are flung

135 "Statistical Information - LDS Newsroom," Newsroom - The Church of Jesus Christ of Latter-day Saints, http:/newsroom.lds.org/ldsnewsroom/eng/statistical-information. 
across the globe, able to share ideas from a living room, coffee shop, library, or any other location with internet access and an available computer, cellular phone, or handheld device. Online communities share information that is instantly available not only to community members, but to the entire Web viewing audience. Anyone who conducts an internet search of a topic will be rewarded with hundreds of results from newspapers, journals, magazines, and books, to personal blogs, journals, and web communities, the most popular of which being forums and message boards. Often a simple registration is required in order to post messages into the forum, but generally messages posted are completely accessible to the reading public. Anyone with internet access and curiosity can peer into a forum on virtually any subject, reading messages and responses from hundreds, sometimes thousands of users. These messages are frozen in time. Responses from 2002 can be brought back to life by a new user who "bumps" the "thread" by responding and bringing the message back to the top of the forum. ${ }^{137}$ In this way, public opinion is frozen in time and space, and simultaneously fluid, since it can be added to indefinitely; web sites and message boards are public conversations where the media and the public interact.

Tensions of the early Church have been immortalized in Mormon history, memorialized in sacred sites across the American landscape, mythologized as history and doctrine, and remain an integral part of Mormon identity. However these tensions no

\footnotetext{
${ }^{137}$ Contemporary "message boards" or "forums" are websites designed for user interaction around common topics. Users can compose open messages to which other uses can respond, creating an ongoing public conversation. Today, message boards exist on every conceivable topic and are used by millions to express views in an open forum. When new messages are posted on the forum, older messages fall to a "lower" position in the forum. When a user goes back to an older post and comments on it, the older post is then brought back up to the top of the message board for further discussion. In this way, topic control is in the hands of the users, topics which receive little attention will be buried beneath other, more lively topics.
} 
Tensions of the early Church have been immortalized in Mormon history, memorialized in sacred sites across the American landscape, mythologized as history and doctrine, and remain an integral part of Mormon identity. However these tensions no longer rule how Americans perceive Mormonism, as the Church has a much stronger hold over its own public relations and place in the media. The official Web Site of the Church is a stylized multi-media presentation, The public face of the Church on the World Wide Web. Visitors to the Church's website can access the complete sacred works of the Church, along with full text Gospel Library, historical archives, maps and photographs of Mormon sacred sites (such as the Temple at Nauvoo and sites along the Mormon Trail), transcripts of General Conference speeches and other public talks, magazine articles, church teachings, full descriptions of Church doctrine, and theology, as well as a wealth of other information. A full listing of Church Presidents with biographies, transcripts of speeches, and more can be accessed through the Church website as well as through websites run by Brigham Young University. Brigham Young University is a Church run and operated full scale Research University with world class research facilities.

In a 2005 Washington Monthly article entitled, “Mitt Romney's Evangelical Problem," author Amy Sullivan laments the Republican Party's dependence on the Evangelical vote (approximately $30 \%$ of the voter base according to Sullivan) in that it would be a major obstacle to Romney's presidential campaign. Sullivan observes, "Evangelicals don't have the same vague anti-LDS prejudice that some Americans do. For them it's...doctrinal... based on very specific theological disputes that can't be 
in the years to come. During the first decade of the twenty-first century, Americans still found Mormons a bit strange, but long gone were the days of outright animosity towards the Church or its people.

Romney's campaign continued to generate public interest throughout 2005-8. A 2006 Time magazine article posed the question to the nation, "A Mormon as President?" Author Mike Allen contributes to the questions raised in the Washington Monthly article, is America ready for a Mormon president? Allen, like Sullivan, points out Americans' ambiguous relationship with Mormonism. Although a significant minority of Americans claims negative views of Mormonism, the majority of the country views the Church as favorably. Polls administered between 2005-2008 shows over a quarter of registered voters would not vote for a Mormon presidential candidate:

Although Mormons are known for family centeredness, hard work and clean living, many Americans remain suspicious of them, maybe because so many aspects of their faith remain mysterious. A poll conducted in June by the Los Angeles Times and Bloomberg found that $35 \%$ of registered voters said they would not consider voting for a Mormon for President. Only Islam would be a more damaging faith for a candidate, the poll found. ${ }^{139}$

Although a substantial minority of those surveyed expressed "unfavorable" opinions of Mormons, public polls and surveys are not perfect mirrors of national public opinion; instead, they provide a window into the larger pattern of the growing acceptance and approval of Mormons in America. Though not as widely favored as more prominent Christian groups, Mormon acceptability closely follows and continues to rise. One reason why Americans may view other Christian denominations more favorably than Mormons is familiarity and dominance, Evangelicals and Catholics have a larger presence in America; Americans have more familiarity with these groups. Mormonism on the whole

\footnotetext{
${ }^{139}$ Allen, Mike. "A Mormon as President?" Time, http:/www.time.com/time/magazine/article/0,9171, 1562941,00.html.
} 
Christian groups, Mormon acceptability closely follows and continues to rise. One reason why Americans may view other Christian denominations more favorably than Mormons is familiarity and dominance, Evangelicals and Catholics have a larger presence in America; Americans have more familiarity with these groups. Mormonism on the whole continues to grow worldwide and as familiarity grows, so too does acceptance and approval. As with any group, Mormons continue to face tensions with the greater society, yet these tensions are nominal and comparable with any other group, they no longer dominate American's view of Mormons.

In 2007, the same year the nation was captivated by Mitt Romney's presidential campaign, the Pew Forum on Religion and Public Life released survey results showing a majority of Americans surveyed (53\%) expressed a favorable opinion of Mormonism while a minority (27\%) expressed unfavorable views; the survey added, "by this measure, the public views Mormons more favorably than Muslims (43\% favorable) and atheists (35\%), but more negatively compared with evangelical Christians ( $60 \%$ favorable), Catholics or Jews (76\% favorable for each group)." 140 Those surveyed tended to view Romney as more religious than the other candidates, yet displayed mixed feelings on voting for a Mormon candidate. These findings support those of the Los Angeles Time poll; again we find that a shrinking minority of Americans disfavor Mormons.

Popular media continues to influence and reflect public perception of Mormons. The early Twenty-First Century saw a barrage of news stories covering issues of

\footnotetext{
${ }^{140}$ Scott Keeter and Gregory Smith, "Pew Research Center: Public Opinion About Mormons," Pew Forum on Religion \& Public Life, http://pewresearch.org/pubs/648/romney-mormon.
} 
polygamy and child-rearing in the $\operatorname{RLDS}^{141}$ Church, children removed from compounds and sent to foster homes while parents were under investigation for practicing plural marriage. This branch, though it maintains the historic site at Kirtland and preserves Mormon history, is not accepted by the Church as representing Mormonism or Mormons.

The popular HBO television program, Big Love, is an example of the public's continuing curiosity about Mormons in the early twenty-first century. Big Love is the fictional and dramatized account of a fictional fundamentalist polygynous family living in Utah. Since its debut in 2006, Big Love has experienced high ratings on the HBO network. As of 2009 , ratings were up $65 \%$ with an average of five million viewers per episode when taking into account episodes recorded and viewed later. ${ }^{142}$

In 2009, Big Love came under fire by Church members for portraying sacred Temple rituals, yet the Church refused to take an official stance. Some Church members, particularly fundamentalist adherents who practice or condone the practice of polygyny, called for a boycott of the program and of other HBO related products. An official statement by the Church denied any official boycott, stating that to do so would only "generate the kind of controversy that the media loves and in the end would increase audiences for the series." ${ }^{143}$ Big Love will continue production as of 2009.

\footnotetext{
${ }^{141}$ Reorganized Church of Jesus Christ of Latter Day Saints, officially named Community of Christ.

${ }^{142}$ Weprin, Alex. "Big Love' Sees Big Growth," News and Information of the Television and Cable Industries-Broadcasting \& Cable, http:/www.broadcastingcable.com/article/173949_Big_Love_Sees_Big Growth.php.

${ }^{143}$ Brachear, Manya, "'Big Love' in big trouble with Mormons," The Chicago Tribune. http://newsblogs.chicagotribune.com/religion_theseeker/2009/03/big-love-in-big-trouble-withmormons.html.
} 
In April of 2009, Utah Valley University will host the Eight Annual Mormon Studies Conference, with topics centered on the question of "Mormonism in the Public Mind." The conference will deal with issues specifically addressed in this paper, such as "the place of Mormonism in public discourse," along with "the strategies involved in the Latter-day Saint response to skepticism and prejudice." 144 Among the topics to be discussed are Mormon public relations strategies. Some of these strategies include Website content and design, missionary training, and advertisements in the media. The Church continues to promote a wholesome image, appealing to those seeking salvation from the secularism and uncertainty of contemporary life.

By the first decade of the twenty-first century, the Church has become exactly that, a mainstream American Church, even a global Church, alongside a plurality of denominations ${ }^{145}$ within the United States. Mormonism is no longer a new religious movement or sect, it is a Church, a community of believers with a distinct identity internalized at a variety of levels by individual members, but generally accepted at some level by most or all members of the community.

\footnotetext{
${ }^{144}$ Utah Valley University, "The UVU Religious Studies Program presents the Eighth Annual Mormon Studies Conference," Dialoguejournal.com, www.dialoguejournal.com/content/wpcontent/uploads/2009/03/2009\%20Mormon $\% 20$ Studies $\% 20$ Conference $\% 20-\% 20$ Schedule.pdf.

${ }^{145}$ Though not fully accepted by Christians as a Christian denomination, from an etic perspective Mormonism has come to belong to the denominational landscape of America.
} 


\section{Conclusion and implications for future research}

In 1865, French critic and historian Hippolyte Taine published an essay in which he anticipated the demise of Mormonism. Taine assumed that "a society founded on principles that were hostile to social laws must inevitably perish." ${ }^{146}$ Contrary to Taine's prediction, the Church did not perish; the "perilous experiment" ${ }^{147}$ was fruitful, and the Church today is a thriving global organization. Those "hostile" principles to which Taine referred, namely the centrality of prophetic leadership, communitarian ideals, and novel religious ideas, were diminished as Utah gained statehood and Mormons gained popular respectability. Throughout the decades of change, the Church has maintained authoritative, vibrant leadership and generally high levels of commitment from its adherents.

The most prominent indications of assimilation during the first few decades of the twentieth century were "were the abandonment of polygamy, theocracy, collectivist economic experiments, the adoption of American 2-party politics, and the embrace of American patriotism." ${ }^{148}$ A process of Christianization also contributed to assimilation, whereby the use of the King James Bible and other Christian elements were emphasized. At midcentury, a process of retrenchment began, most obvious in the last few decades of

\footnotetext{
${ }^{146}$ Austin E. Fife, "Taine's Essay on the Mormons," The Pacific Historical Review 31 (1962): 50.

${ }^{147}$ Austin E. Fife, "Taine's Essay on the Mormons," The Pacific Historical Review 31 (1962): 50.

${ }^{148}$ Morehead, John, "Interview with Armand Mauss: Implications of Mormon Assimilation and Retrenchment," Morehead's Musings. http://johnwmorehead.blogspot.com/2008/01/armand-mauss-onangel-and-beehive.html.
} 
the twentieth century. Indications of the retrenchment process are outlined by Mauss and included:

... a new emphasis upon use of the Book of Mormon; a renewed focus on the president of the church as a prophet (with additions to the D \& C for the first time in the century, recurrent slogans about following the prophet and obedience)... a great expansion in such "peculiar" Mormon programs as genealogy, temple-building, missionary work, and religious education (seminary and institute programs)-all of which had languished for decades; and finally a renewal and redefinition of the LDS theology of the family, with a conservative definition of women's roles and an ongoing program to bolster the nuclear family institution as a bulwark against the creeping vices of sexual indulgence, substance use or abuse, and many other social ills afflicting American society since the $1960 \mathrm{~s} .{ }^{149}$

The global spread of the Church and the evolution of myth, history, and collective memory are areas of great interest which may provide a wealth of information related to contemporary Mormon identity. The growth and spread of a new religious movement provides models for theological, political, historical, and economic studies, the Church in America is such an ideal model with much room for future studies. Brigham Young University, officially tied to the Church, has developed archives that have been of use to scholars in a variety of fields, and the Church continues to be investigated by scholars within and outside of the Church.

Besides the international growth of the Church, the process of memorialization of sacred space and the incorporation of sacred space into Mormon identity is an area of great interest where strides need to be made. Strewn across America, sacred sites document the history of Mormonism. These sites are being reclaimed by the Church and related groups and transformed into historical and tourist destinations. Sites along the Mormon Trail commemorate and often romanticize Mormon history for a larger American public as well as provide a friendly face for the Church. Clean-cut, friendly

\footnotetext{
${ }^{149}$ Morehead, John, "Interview with Armand Mauss: Implications of Mormon Assimilation and Retrenchment," Morehead's Musings. http://johnwmorehead.blogspot.com/2008/01/armand-mauss-onangel-and-beehive.html.
} 
Mormon Trail commemorate and often romanticize Mormon history for a larger American public as well as provide a friendly face for the Church. Clean-cut, friendly workers at these sites present Americans with a positive assessment of Mormons and Mormonism and can even serve as an evangelical tool.

As we have seen, early Mormons shared a sense of collective identity in relation to the sectarian American religious landscape, built on "sharp boundaries between themselves and surrounding 'gentile' settlements." ${ }^{150}$ Mormon identity is conspicuously grounded in its history, and Mormon history has been since the beginning and remains a "vital aspect of Latter-day Saints' collective identity."151 "We...learn our identities as reference group members vis-à-vis other groups, the "us versus them' identity." ${ }^{\prime 152}$ With the dawn of the twentieth century, an observable decrease in conflict and increase in public acceptance of Mormons occurred, a "routinization of charisma" took place, whereby a fiery Church forged in persecution and conflict was transformed into a fullfledged theocratic bureaucracy (internally, at any rate), a flourishing, conservative, American Church.

Public perception does not exist as a uniform entity that can be easily assessed; rather it is an abstract concept that can be measured to some extent through the popular media and public responses to such. In measuring popular opinion, poll and survey results can offer assistance, as can newspapers, magazines, the World Wide Web, and

\footnotetext{
${ }^{150}$ Laurence R. Moore, "Insiders and Outsiders in American Historical Narrative and American History," The American Historical Review 87 (1982): 400.

${ }^{151}$ Michael H. Madsen, "The Sanctification of Mormonism's Historical Geography." Journal of Mormon History 34 (2008): 229.

${ }^{152}$ Armand L. Mauss, "Identity and Boundary Maintenance: International Prospects for Mormonism at the Dawn of the Twenty-first Century," in Mormon Identities in Transition, ed. Douglas Davies (New York: Cassell, 1996), 10.
} 
groups all vying for space and sway in the public landscape. The "general public" can only be spoken of in relation to one or another of these groups, in this case, the LDS Church. Public opinion, the opinions of the majority or vocal minorities, has worked in conjunction with the Church's own internal (top-down) perceptions of itself. The Church's well-oiled public image campaign is a direct response to negative public perceptions of Mormons.

The Church's highly controlled public image campaign is evident in its highly organized and carefully designed website as much as in its clean-cut and highly trained global missionaries. The sacred duty of mission work is one in which many young Mormon men and women undertake. As of 2007, the Church claims 53,000 missionaries serving in "over 350 missions in 162 nations," with over a million missions having been served since the founding of the Church. ${ }^{153}$ Missionaries work on diverse projects ranging from humanitarian aid to pure proselytization. The fresh faced missionaries of the Church, trained in persuasion, rhetoric, and various languages, are the physical embodiment of the Church's public image campaign. Devout missionaries reach out to communities in need, providing humanitarian aid and offering a clearly defined worldview with a clear and organized value system.

As a new religious movement founded in America, Mormonism is a picture of successful acculturation. The acculturation process is comparable to the progression from sect to Church. Mormonism perceives itself as a restorationist Christian movement; as such it has progressed from an early sectarian movement to a large scale institution that

\footnotetext{
153 "One Million Missionaries, Thirteen Million Members," Newsroom: The Church of Jesus Christ of Latter-day Saints, http://newsroom.lds.org/ldsnewsroom/eng/news-releases-stories/one-millionmissionaries-thirteen-million-members.
} 
sect to Church. Mormonism perceives itself as a restorationist Christian movement; as such it has progressed from an early sectarian movement to a large scale institution that provides direction, meaning, and value to the lives of its participants. Historically, the Church experienced decreasing levels of conflict with the larger society as it underwent a process of routinization. The Church remains vital through retaining its distinctiveness, but this was only possible after the preceding periods of assimilation and decreased tension. The Church has already seen some branching off, as is the case with the RLDS Church, yet the mainstream Church has remained intact institutionally.

As a large scale cultural and religious institution, the Church has maintained a distinct identity while continuing to meet the needs of adherents. Church authority maintains a hierarchical power structure that is reflected in the community and in the home. For believers, the Church continues to provide meaning and order; its myths, stories, and rituals remain vibrant and efficacious. Mormonism remains a topic of fascination-both religious and cultural ${ }^{154}$-for Americans that will certainly persist into the twenty-first century. We have seen the Church experience conflict, undergo assimilation, reclaim its distinctiveness, and finally, maintain a balance between acceptance and otherness; this careful balance was negotiated historically and progressively.

\footnotetext{
${ }^{154}$ See the great Mormon Temple in Utah, the world famous Tabernacle Choir, and contemporary film makers such as Jared and Jerusha Hess for just a few examples of cultural contributions made by Mormons.
} 
"1844 Nauvoo Expositor newspaper: pages 1-2." Early Mormonism Collection 2. http://solomonspalding.com/docs/exposit1.htm\#pglclb (accessed January 20. 2009).

Abanes, Richard. One Nation Under Gods: A History of the Mormon Church. New York: Thunder's Mouth Press, 2003.

Allen, Mike. "A Mormon as President?." Time. http://www.time.com/time/magazine/article/0,9171,1562941,00.html (accessed March 25, 2009).

"Approaching Mormon History - LDS Newsroom ." Newsroom - The Church of Jesus Christ of Latter-day Saints . http://newsroom.lds.org/ldsnewsroom/eng/commentary/approaching-mormonhistory (accessed December 5, 2008).

Arrington, Leonard J., and Davis Bitton. The Mormon Experience: A History of the Latter-Day Saints. Urbana: University of Illinois Press, 1992.

"AskOxford: Free online dictionary resources from Oxford University Press." Oxford University Press. http://www.askoxford.com/?view=uk (accessed December 15, 2008).

Bagley, Will. Blood of the Prophets: Brigham Young and the Massacre at Mountain Meadows. Norman: University of Oklahoma Press, 2004.

Bednarowski, Mary Farrell. The Religious Imagination of American Women (Religion in North America). Bloomington: Indiana University Press, 1999.

Berger, Peter L., and Thomas Luckmann. Social Construction of Reality: A Treatise in the Sociology of Knowledge. New York: Doubleday Anchor, 1967.

Berger, Peter L.. The Sacred Canopy. New York: Doubleday, 1967.

Brachear, Manya. "'Big Love' in big trouble with Mormons." The Chicago Tribune. http://newsblogs.chicagotribune.com/religion theseeker/2009/03/big-love-in-bigtrouble-with-mormons.html (accessed March 26, 2009).

Brooks, Juanita. The Mountain Meadows Massacre. Norman: University of Oklahoma Press, 1991.

Bushman, Claudia L. Contemporary Mormonism: Latter-day Saints in Modern America. 
Bushman, Claudia L. Contemporary Mormonism: Latter-day Saints in Modern America. Westport, CT: Praeger Publishers, 2006.

Bushman, Claudia Lauper, and Richard Lyman Bushman. Building the Kingdom: A History of Mormons in America. New York: Oxford University Press, USA, 2001.

Bushman, Richard Lyman. "Joseph Smithâ€ $\mathfrak{T M}_{\mathrm{S}}$ Place in History: A Biographical Foreword." The Joseph Smith Papers. josephsmithpapers.org/Essays/Bushman.pdf (accessed January 9, 1930).

Cannon, M. Hamlin. "Contemporary Views of Mormon Origins." The Mississippi Valley Historical Review 31 (1944): 261-266.

Caswall, Henry. "City of the Mormons, 1842." Joseph Smith's History Vault, Archives. olivercowdery.com/smithhome/1840s/1842Cas1.htm (accessed December 5, 2008).

Cerulo, Karen A.. "Identity Construction: New Issues, New Directions." Annual Review of Sociology 23 (1997): 385-409.

Chidester, David, and Edward T. Linenthal. American Sacred Space (Religion in North America). Bloomington: Indiana University Press, 1996.

"Church Growth and Lamanite Involvement - Spencer W. Kimball." Speeches. http://speeches.byu.edu/reader/reader.php?id=6059 (accessed February 9, 2009).

Cornwall, Marie, Tim B. Heaton, and Lawrence A. Young. Contemporary Mormonism: Social Science Perspectives. Urbana: University of Illinois Press, 2001.

Cote, James E., and Charles G. Levine. Identity, Formation, Agency, and Culture: A Social Psychological Synthesis. NY: LEA, Inc., 2002.

Cracroft, Richard H. "'The Assault on Laughter": The Comic Attack on Mormon Polygamy in Popular Literature." Journal of Mormon History 34 (2008): 233262.

"David O. McKay, 9th President of the Church." The Church of Jesus Christ of Latterday Saints.

http://www.lds.org/churchhistory/presidents/controllers/potcController.jsp?leader $=9 \&$ topic $=$ facts (accessed February 17, 2009).

Davies, Douglas. Mormon Identities in Transition (Cassell Religious Studies). London: Cassell, 1996. 
Decoo, Wilfried. "Mormon identity and culture." Times \& Seasons. http://timesandseasons.org/index.php/2008/03/mormon-identity-and-culture/ (accessed December 20, 2008).

Dillon, Michele. Handbook of the Sociology of Religion. New York: Cambridge University Press, 2003.

Dorson, Richard M.. Buying the Wind: Regional Folklore in the United States (Phoenix Books). Chicago: University Of Chicago Press, 1972.

Duffy, John-Charles. "The Use of "Lamanite" in Official LDS Discourse." Journal of Mormon History 34 (2008): 118-167.

Durkheim, Emile. The Elementary Forms of Religious Life (Oxford World's Classics). New York: Oxford University Press, USA, 2001.

Eliason, Eric A. "Curious Gentiles and Representational Authority in the City of the Saints." eligion and American Culture 11 (2001): 155-190.

Eliason, Eric A. "Meridian Magazine: The Life and Lore of J. Golden Kimball â€" Mormon Folk Hero ." Meridian Magazine. http://www.meridianmagazine.com/arts/070927kimball.html (accessed March 11, 2009).

Eliason, Eric A. . Mormons and Mormonism: An Introduction to an American World Religion. Urbana: University of Illinois Press, 2001.

Eliason, Eric A.. "The Life and Lore of J. Golden Kimball - Mormon Folk Hero." Meridian Magazine: The Place Where Latter-day Saints Gather. http://www.meridianmagazine.com/arts/070927kimball.html\#_ednref2 (accessed January 16, 2009).

"Far West ." The Church of Jesus Christ of Latter-day Saints. http://www.lds.org/placestovisit/location/0,10634,1808-1-1-1,00.html (accessed December 1, 2008).

Fife, Austin E. "Taine's Essay on the Mormons." The Pacific Historical Review 31 (1962): 49-65.

Flanders, Robert. Nauvoo: KINGDOM ON THE MISSISSIPPI. Urbana: University of Illinois Press, 1975.

Foote, Kenneth E.. Shadowed Ground: America's Landscapes of Violence and Tragedy. Austin: University of Texas Press, 2003. 
Fox, Russell Arben. "Mormonism and American Politics Conference at Princeton | Times \& Seasons, An Onymous Mormon Blog." Times \& Seasons, An Onymous Mormon Blog. http://timesandseasons.org/index.php/2007/10/mormonism-andamerican-politics-conference-at-princeton/ (accessed February 1, 2009).

Gardner, Hamilton. "Cooperation Among the Mormons." The Quarterly Journal of Economics 31 (1917): 461-499.

Geertz, Clifford. The Interpretation of Cultures. New York: HarperCollins Publishers, 1973.

Givens, Terryl. The Viper on the Hearth: Mormons, Myths, and the Construction of Heresy (Religion in America). New York: Oxford University Press, USA, 1997.

Goldberg, Robert Alan. Enemies Within: The Culture of Conspiracy in Modern America. New Haven: Yale University Press, 2001.

Hardy, B. Carmon. Solemn Covenant: The Mormon Polygamous Passage. Urbana: University of Illinois Press, 1992.

Harner, John. "Place Identity and Copper Mining in Sonora, Mexico." Annals of the Association of American Geographers 91 (2001): 660-680.

Herberg, Will. Protestant--Catholic--Jew: An Essay in American Religious Sociology. Chicago: University Of Chicago Press, 1983.

"History of the Church." The Church of Jesus Christ of Latter-day Saints. http://www.lds.org/churchhistory/history (accessed November 15, 2008).

Iannaccone, Laurence R, and Carrie A Miles. "Dealing with Social Change: The Mormon Church's Response to Change in Women's Roles." Social Forces 68 (1990): 1231-1250.

"Independence Visitors' Center ." The Church of Jesus Christ of Latter-day Saints . http://www.lds.org/placestovisit/location/0,10634,1812-1-1-1,00.html (accessed December 1, 2008).

"James Abram Garfield: Inaugural address, Friday, March 4, 1881." From Revolution to Reconstruction. www.let.rug.nl/usa/P/jg20/speeches/garfield.htm (accessed December 1, 2008).

Jensen, Marlin K.. "Church History: Past, Present and Future." Journal of Mormon History 34 (2008): 20-42.

Johnson, Benjamin H. Making of the American West: People and Perspectives. Santa 
Barbara, CA: ABC-CLIO, 2007.

Johnson, Martin, and Phil Mullins. "Mormonism: Catholic, Protestant, Different?." Review of Religious Research 34 (1992): 51-62.

Keeter, Scott, and Gregory Smith. "Pew Research Center: Public Opinion About Mormons." Pew Forum on Religion \& Public Life. http://pewresearch.org/pubs/648/romney-mormon (accessed December 15, 2008).

Kimball, Spencer W, N. Eldon Tanner, and Marion G Romney. "Official Declaration 2." Scriptures. http://scriptures.lds.org/en/od/2 (accessed February 12, 2009).

"Kirtland Temple History." Kirtland Temple Historic Center. http://www.kirtlandtemple.org/history.html (accessed February 2, 2009).

Launius, Roger D., and John E. Hallwas. Kingdom on the Mississippi Revisited: NAUVOO IN MORMON HISTORY. Urbana: University of Illinois Press, 1996.

Lesueur, Stephen C.. The 1838 Mormon War in Missouri. Columbia, MO: University of Missouri Press, 1990.

Ludlow, Daniel H.. "Encyclopedia of Mormonism." Harold B. Lee Library. http://www.lib.byu.edu/Macmillan/ (accessed January 15, 2009).

Madsen, Michael H.. "The Sanctification of Mormonism's Historical Geography." Journal of Mormon History 34 (2008): 228-255.

Mauss, Armand L. "Comments: White on Black among the Mormons: A Critique of White \& White." Sociological Analysis 42 (1981): 277-282.

Mauss, Armand L. "Sociological Perspectives on the Mormon Subculture." Annual Review of Sociology 10 (1984): 437-460.

Mauss, Armand L., and Philip Barlow. "Church, Sect, and Scripture: The Protestant Bible and Mormon Sectarian Retrenchment." Sociological Analysis 52 (1991): 397414.

Mauss, Armand L.. The Angel and Beehive: The Mormon Struggle with Assimilation. Urbana: University of Illinois Press, 1994.

Mayrl, William W.. "Marx' Theory of Social Movements and The Church-Sect Typology." Sociological Analysis 37 (1976): 19-31.

Meinig, D. W.. "The Mormon Culture Region: Strategies and Patterns in the Geography 
of the American West, 1847-1964." Annals of the Association of American Geographers 55 (1965): 191-220.

Moore, Laurence R. "Insiders and Outsiders in American Historical Narrative and American History." The American Historical Review 87 (1982): 390-412.

Moore, R. Laurence. Religious Outsiders and the Making of Americans. New York: Oxford University Press, USA, 1986.

Morehead, John. "Interview with Armand Mauss: Implications of Mormon Assimilation and Retrenchment." Morehead's Musings.

http://johnwmorehead.blogspot.com/2008/01/armand-mauss-on-angel-andbeehive.html (accessed February 15, 2009).

"Mormon Pioneer National Historic Trail (U.S. National Park Service)." National Park Service - Experience Your America. http://www.nps.gov/mopi/ (accessed December 1, 2008).

N., Richard, and Joan K. Ostling. Mormon America The Power and the Promise. New York: HarperCollins, 1999.

"One Million Missionaries, Thirteen Million Members." Newsroom: The Church of Jesus Christ of Latter-day Saints. http://newsroom.lds.org/ldsnewsroom/eng/newsreleases-stories/one-million-missionaries-thirteen-million-members (accessed February 18, 2009).

Park, Chris. Sacred Worlds: An Introduction to Geography an Religion. New York: Routledge, 1994.

Paul, Rodman W. "The Mormons As a Theme in Western Historical Writing." The Journal of American History 54 (1967): 511-523.

Peterson, Janet, and Connie Lewis. "Making a Difference for Women: Belle S. Spafford." Ensign, Winter 2006.

http://www.lds.org/ldsorg/v/index.jsp?vgnextoid=2354fccf $2 \mathrm{~b} 7 \mathrm{db} 010 \mathrm{VgnVCM} 10$ $00004 \mathrm{~d} 82620 \mathrm{aRCRD} \&$ locale $=0 \&$ sourceId $=\mathrm{d} 0 \mathrm{e} 58 \mathrm{ebebcd} 6 \mathrm{c} 010 \mathrm{VgnVCM} 100000$ 4d82620a__ \&hideNav=1 (accessed January 25, 2009).

"Pew Forum: Public Expresses Mixed Views of Islam, Mormonism." Pew Forum on Religion \& Public Life. http://pewforum.org/surveys/religionviews07/\#section2 (accessed February 1, 2009).

"Prosperity \& Protest." TIME.com. http://www.time.com/time/magazine/article/0,9171,836990,00.html (accessed February 5, 2009). 
Puhala, Bob, and Lyndee Jobe Henderson. Illinois Off the Beaten Path, 9th (Off the Beaten Path Series). New York: Globe Pequot, 2007.

The New York Times. December 18, 1904. "Refuses to Produce Secret Mormon Books; Recorder at Smoot Inquiry Says He Would Rather Go To Jail..". http://query.nytimes.com/gst/abstract.html?res=9805E3DF1F3BE631 A2575BC1 A9649D946597D6CF (accessed December 5, 2008).

Richards, Claude. J. Golden Kimball: The story of a unique personality. Salt Lake City, UT: Bookcraft, 1966.

Schwartz, Regina M.. The Curse of Cain: The Violent Legacy of Monotheism. Chicago: University Of Chicago Press, 1997.

Schwartz, Regina M.. The Curse of Cain. Chicago: University Of Chicago Press, 1997.

Scianna, Anna. "Missouriâ€ $\mathrm{TM}_{\mathrm{S}}$ Mormon past - Columbia Missourian." Columbia Missourian. http://www.columbiamissourian.com/stories/2006/10/15/missourismormon-past/ (accessed November 1, 2008).

Shepherd, Gary, and Gordon Shepherd. Mormon Passage: A Missionary Chronicle. Urbana: University of Illinois Press, 1998.

Shepherd, Gordon, and Gary Shepherd. "Mormonism in Secular Society: Changing Patterns in Official Ecclesiastical Rhetoric." Review of Religious Research 26 (1984): 28-42.

Shipps, Jan. Sojourner in the Promised Land: Forty Years Among the Mormons. Urbana: University of Illinois Press, 2006.

Smith, George Albert. "A Peculiar People." TIME.com. http://www.time.com/time/magazine/article/0,9171,779210,00.html (accessed February 5, 2009).

Smith, Joseph. "The Book of Mormon: Introduction." Scriptures. http://scriptures.lds.org/en/bm/introduction (accessed December 12, 2008).

Stark, Rodney, and Reid L. Neilson. The Rise of Mormonism. Columbia: Columbia University Press, 2005.

Stark, Rodney. "So Far, So Good: A Brief Assessment of Mormon Membership Projections." Review of Religious Research 38 (1996): 175-178.

"Statistical Information - LDS Newsroom." Newsroom - The Church of Jesus Christ of 
Latter-day Saints. http://newsroom.lds.org/ldsnewsroom/eng/statisticalinformation (accessed February 20, 2009).

Stegner, Wallace. Mormon Country. Toronto, Canada: Bison Books, 2003.

Stegner, Wallace. The Gathering of Zion: The Story of the Mormon Trail. Toronto, Canada: Bison Books, 1992.

Sullivan, Amy. "Mitt Romney's Evangelical Problem." The Washington Monthly. http://www.washingtonmonthly.com/features/2005/0509.sullivan1.html (accessed March 25, 2009).

"The Family: A Proclamation to the World." The Church of Jesus Christ of Latter-day Saints. http://www.lds.org/library/display/0,4945,161-1-11-1,00.html (accessed January 20, 2009).

"The Mormons . Interviews . Jeffrey Holland | PBS." PBS.

http://www.pbs.org/mormons/interviews/holland.html (accessed December 15, 2008).

"The Mormons . Interviews . Kathleen Flake | PBS." PBS. http://www.pbs.org/mormons/interviews/flake.html (accessed October 1, 2008).

"The Mormons . Interviews . Terryl Givens | PBS." PBS. http://www.pbs.org/mormons/interviews/givens.html (accessed December 1, 2008).

Twain, Mark. Roughing It. New York: Harper And Brothers, 1913.

Underwood, Grant. The Millenarian World of Early Mormonism. Urbana: University of Illinois Press, 1993.

Utah Valley University. "The UVU Religious Studies Program presents the Eighth Annual Mormon Studies Conference." dialoguejournal.com. www.dialoguejournal.com/content/wpcontent/uploads/2009/03/2009\%20Mormon\%20Studies\%20Conference $\% 20$ $\% 20$ Schedule.pdf (accessed March 27, 2009).

Vance, Laura. "Evolution of Ideals for Women in Mormon Periodicals, 1897-1999." Sociology of Religion 63 (2002): 91-112.

"Visit Historic Far West." Far West Historical Society. http://www.farwesthistorical.org/ (accessed December 1, 2008).

Weprin, Alex. "'Big Love' Sees Big Growth." News and Information of the Television 
and Cable Industries-Broadcasting \& Cable.

http://www.broadcastingcable.com/article/173949-

_Big_Love_Sees_Big_Growth.php (accessed March 27, 2009).

White, Jr, O. Kendall, and Daryl White. "Abandoning an Unpopular Policy: An Analysis of the Decision Granting the Mormon Priesthood to Blacks." Sociological Analysis 41 (1980): 231-245.

White, Jr., O. Kendall, and Daryl White. "Integrating Religious and Racial Identities: An Analysis of LDS African American Explanations of the Priesthood Ban." Review of Religious Research 36 (1995): 295-311.

Whitmer, John. "Book of John Whitmer." The Book of Abraham Project. http://www.boap.org/LDS/Early-Saints/JWhitmer-history.html (accessed December 1, 2008).

Whitney, Helen, Jane Barnes, and Ted Winterburn. "The Mormons: People \& Events: PBS." PBS. http://www.pbs.org/mormons/peopleevents/e_opposition.html (accessed October 1, 2008).

Wilson, William A.. "Mormon Narratives: The Lore of Faith." Western Folklore 54 (1995): 303-326 .

Encyclopedia of Women And Religion in North America. Bloomington: Indiana University Press, 2006. 